\title{
Untangling phylogenetic patterns and taxonomic confusion in tribe Caryophylleae (Caryophyllaceae) with special focus on generic boundaries
}

\author{
Hossein Madhani, ${ }^{1}$ Richard Rabeler, ${ }^{2}$ Atefeh Pirani, ${ }^{3}$ Bengt Oxelman, ${ }^{4}$ Guenther Heubl ${ }^{5}$ Shahin Zarre $^{1}$ \\ 1 Department of Plant Science, Center of Excellence in Phylogeny of Living Organisms, School of Biology, College of Science, \\ University of Tehran, P.O. Box 14155-6455, Tehran, Iran \\ 2 University of Michigan Herbarium-EEB, 3600 Varsity Drive, Ann Arbor, Michigan 48108-2228, U.S.A. \\ 3 Department of Biology, Faculty of Sciences, Ferdowsi University of Mashhad, P.O. Box 91775-1436, Mashhad, Iran \\ 4 Department of Biological and Environmental Sciences, University of Gothenburg, Box 461, 40530 Göteborg, Sweden \\ 5 Biodiversity Research - Systematic Botany, Department of Biology I, Ludwig-Maximilians-Universität München, Menzinger Str. 67, \\ 80638 München, Germany; and GeoBio Center LMU \\ Author for correspondence: Shahin Zarre, zarre@khayam.ut.ac.ir
}

DOI https://doi.org/10.12705/671.6

\begin{abstract}
Assigning correct names to taxa is a challenging goal in the taxonomy of many groups within the Caryophyllaceae. This challenge is most serious in tribe Caryophylleae since the supposed genera seem to be highly artificial, and the available morphological evidence cannot effectively be used for delimitation and exact determination of taxa. The main goal of the present study was to re-assess the monophyly of the genera currently recognized in this tribe using molecular phylogenetic data. We used the sequences of nuclear ribosomal internal transcribed spacer (ITS) and the chloroplast gene rps16 for 135 and 94 accessions, respectively, representing all 16 genera currently recognized in the tribe Caryophylleae, with a rich sampling of Gypsophila as one of the most heterogeneous groups in the tribe. Phylogenetic trees were reconstructed using maximum parsimony and Bayesian inference methods. The results show that most of the large genera of Caryophylleae are not monophyletic. As a result, we propose a new classification system matching both molecular phylogenetic and morphological evidence. The main taxonomic conclusions include: (1) the description of three new genera, (2) treating five small genera as synonyms, (3) resurrecting the genus Heterochroa with six species, and (4) proposing 23 new combinations plus 2 replacement names at the specific level. As a result, we recognize 14 genera in Caryophylleae. A diagnostic key to all genera of Caryophylleae is provided.
\end{abstract}

Keywords carnation; Dianthus; Gypsophila; Saponaria; systematics; taxonomic revision

Supplementary Material DNA sequence alignments are available from https://doi.org/10.12705/671.6.S

\section{INTRODUCTION}

Assigning correct names to plant taxa as the basic elements of ecosystems is a critical first step for any biodiversity inventory or monitoring program. Such inventory programs are very important for resource management and conservation planning. In the flora of SW Asia, Caryophyllaceae are abundant in various natural ecosystems, but the delimitation of taxa in the family is problematic with issues such as clinal trends in morphological traits blurring the borders between taxa, frequent hybridization in some genera (such as Dianthus L., see Vítová \& al., 2015), and seemingly artificial taxonomic borders appearing at various ranks.

The focal group of the present study is tribe Caryophylleae Lam. \& DC., including about 630 species assigned currently to 16 genera (Hernández-Ledesma \& al., 2015). It is, after tribe Sileneae DC., the second-largest tribe in family Caryophyllaceae (Bittrich, 1993; Harbaugh \& al., 2010; Greenberg \& Donoghue, 2011; Pirani \& al., 2014; HernándezLedesma \& al., 2015; R. Rabeler, personal data). The members of the tribe are primarily Holarctic, with their diversity centered in Mediterranean and Irano-Turanian regions and few taxa extending to Africa. Like many other members of the large clade Plurcaryophyllaceae (sensu Greenberg \& Donoghue, 2011), they are perennial or annual herbs, sometimes woody at base or even spiny cushions (e.g., Acanthophyllum C.A.Mey. spp.) characterized by five fused sepals, five more or less clawed petals, ten free stamens, and capsules opening with four, or rarely six, teeth (Bittrich, 1993). Some representative images of these plants are presented in Fig. 1. Contrary to the members of closely related tribe Sileneae, the commissural veins are absent or scarcely evident on the calyx tube in members of Caryophylleae. Many species are well-known ornamental plants (e.g., carnation: Dianthus spp., baby's-breath: Gypsophila L. spp.), used as source of triterpene saponins (e.g., Acanthophyllum spp.), or known as important weeds (e.g., Gypsophila spp.). Some species are important components of mountainous steppes (e.g., Acanthophyllum spp.) or saxicolous vegetation (e.g., Dianthus spp., Gypsophila spp.) in Europe, Central and Southwest (SW) Asia. The largest

Article history: Received: 12 Feb 2017 | returned for (first) revision: 6 Apr 2017 | (last) revision received: 29 Oct 2017 | accepted: 20 Nov 02017 | published: online fast track, n/a; in print and online issues, 6 Mar 2018 || Associate Editor: Sigrid Liede-Schumann || (C International Association for Plant Taxonomy (IAPT) 2018, all rights reserved 
genera are Dianthus (ca. 300 spp.), Gypsophila (ca. 150 spp.), Acanthophyllum (ca. 90-100 spp.), Petrorhagia (Ser.) Link (ca. 33 spp.), and Saponaria L. (ca. 30 spp.).

The monophyly of tribe Caryophylleae and some of its large genera such as Dianthus and Acanthophyllum are confirmed by both morphological and molecular evidence (Fior \& al., 2004; Harbaugh \& al., 2010; Greenberg \& Donoghue, 2011; Pirani \& al., 2014), although some transfers and synonymy are still necessary to make these genera entirely monophyletic. Dianthus (including Velezia L.) as the largest genus of the tribe
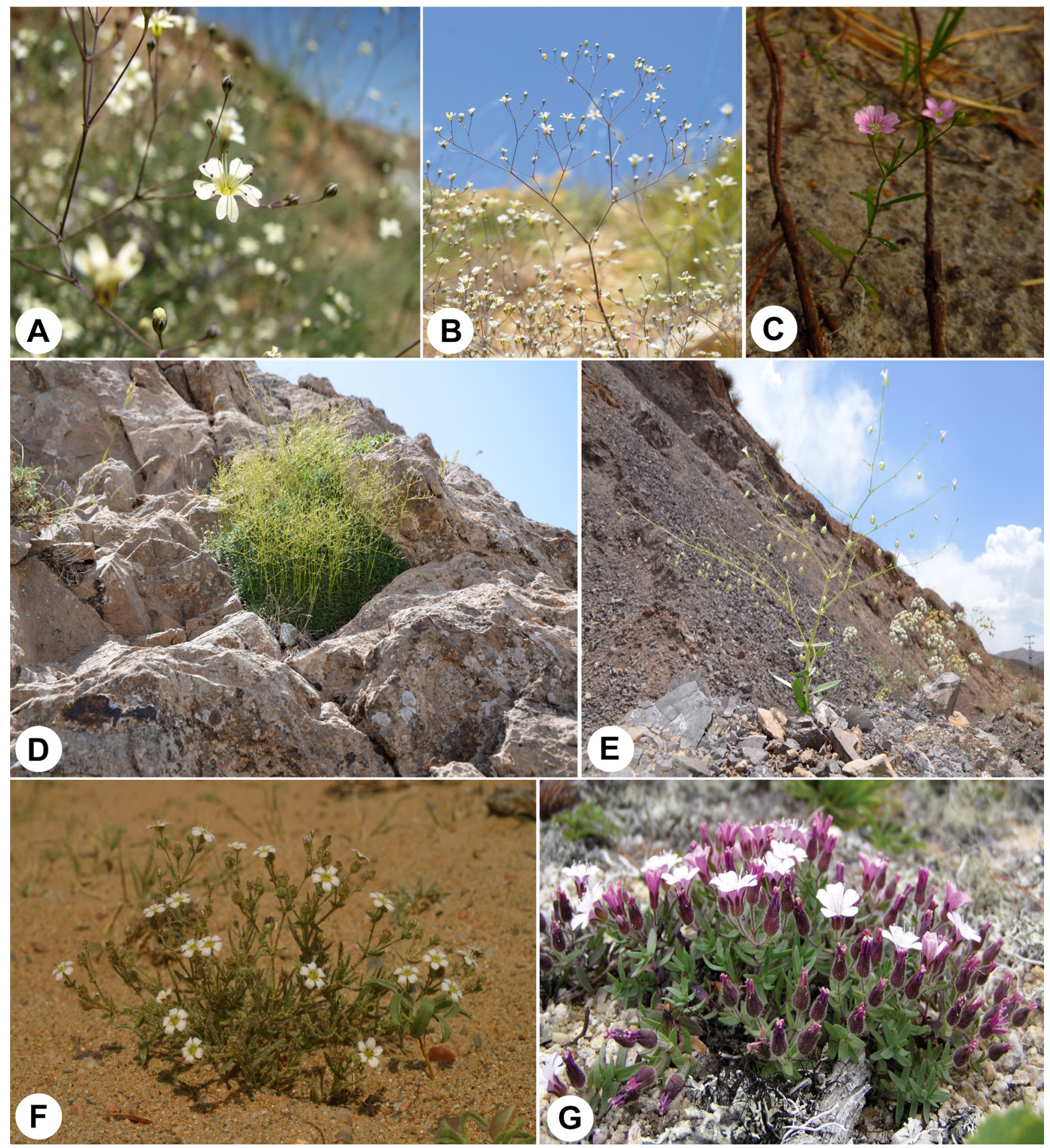

Fig. 1. (in two parts) Selected members of Caryophylleae in their natural habitat. A \& B, Gypsophila leioclada (by H. Madhani); C, Psammophiliella muralis (by Natalia Gamow); D, Gypsophila acantholimoides (by H. Madhani); E, G. pilosa (by H. Madhani); F, G. desertorum (by Martin Schnittler in http://floragreif.uni-greifswald.de); G, G. violacea (by I. Khan in http://www.plantarium.ru); (continued on next page) 
is monophyletic (Harbaugh \& al., 2010; Valente \& al. 2010; Greenberg \& Donoghue, 2011) and is characterized by the presence of an epicalyx consisting of discrete bracteoles subtending the calyx (except Velezia), numerous fine veins on the calyx tube, and dentate or fimbriate petal apices in most species.
Acanthophyllum, with a predominantly cushion habit and spiny leaves, should include taxa formerly assigned to Allochrusa Bunge, Ochotonophila Gilli, Scleranthopsis Rech.f. and part of Diaphanoptera Rech.f (Pirani \& al., 2014). However, the monophyly of other genera such as Bolanthus (Ser.) Rchb.,
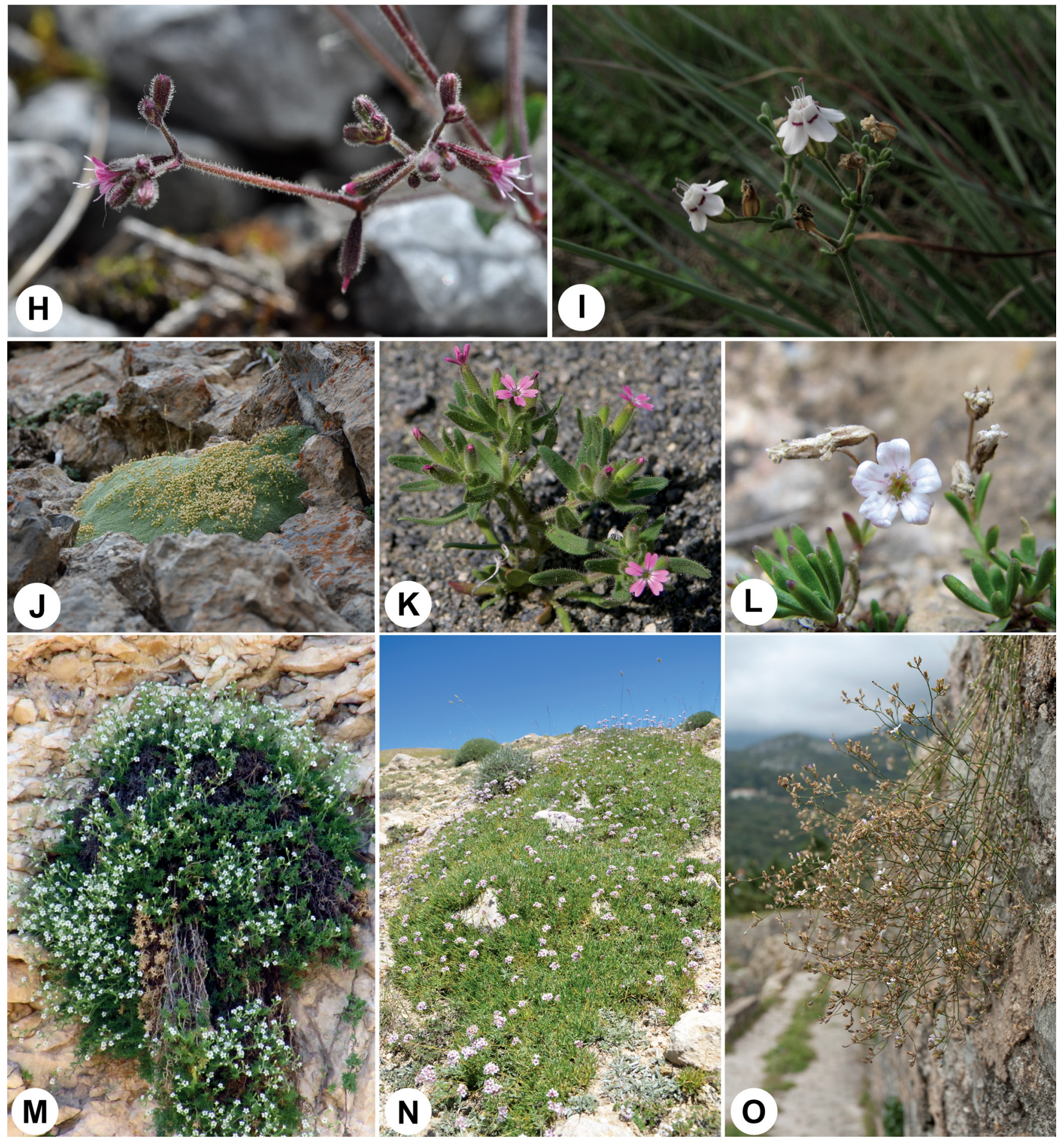

Fig. 1. (continued from previous page) $\mathbf{H}$, Psammosilene tunicoides (by J.T. Johansson in http://angio.bergianska.se); I, Bolanthus fruticulosus (by Armin Jagel); J, G. aretioides (by H. Madhani); K, Saponaria viscosa (by S. Banquet in http://www.plantarium.ru); L, G. saponarioides (by H. Madhani); M, Gypsophila montserratii (by A. Gutiérrez \& S. Fajarnés); N, Gypsophila bazorganica (by Navid Madhani); 0, Petrorhagia saxifraga (by D. Oreshkin in http://www.plantarium.ru). 


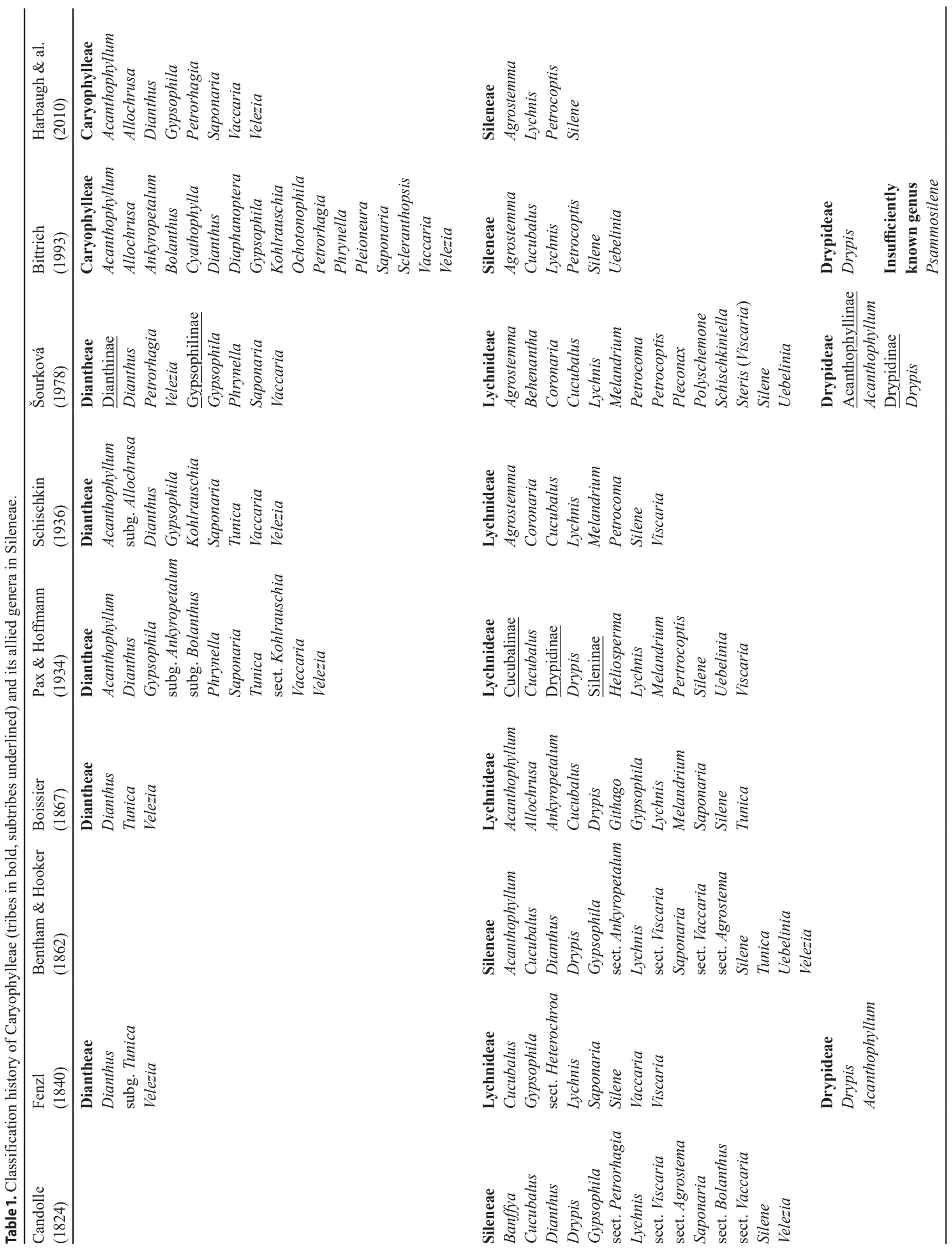


Gypsophila, Petrorhagia, Saponaria, and Vaccaria Wolf has not been adequately addressed (Kadereit $\&$ al., 2016) in previous molecular phylogenetic studies (Fior \& al., 2006; Harbaugh $\&$ al., 2010; Greenberg \& Donoghue, 2011).

The taxonomy of this group has been subject of several treatments (for a review, see Table 1). The confusion began as Haller (1742) described Tunica with the names Dianthus and Caryophyllus below it (probably as synonyms or equivalents). Without naming any species of Tunica, Ludwig (1757) applied this name beside Dianthus, making the former a synonym of the latter. Using the generic name Tunica, replacing Dianthus, was followed by Scopoli (1771) when he replaced even the type of Dianthus with a Tunica (as T. caryophyllus (L.) Scop.). Tunica was later used by several authors (e.g., Boissier, 1867) as a genus distinct from Dianthus; the genus in this usage is now treated as a synonym of Petrorhagia (for a detailed bibliography see Ball \& Heywood, 1964). In addition, Linnaeus (1753) could not clearly delimit Gypsophila, Saponaria, and Tunica; some of the species that he described as members of Gypsophila are considered today as members of Saponaria, Petrorhagia, and Arenaria L. There are only four genera of Caryophylleae (Dianthus, Gypsophila, Saponaria, Velezia) in its modern definition (sensu Harbaugh \& al., 2010) that were first described by Linnaeus (1753). These genera plus a few more were assigned to tribe Sileneae by Candolle (1824). Among the genera currently assigned to Caryophylleae, six genera were recognized by Fenzl (1840) who classified them in three different tribes: Diantheae, Lychnideae Fenzl and Drypideae Fenzl. Bentham (1862) put all these genera in tribe Sileneae. In Flora Orientalis, Boissier (1867) adopted a system almost similar to Fenzl (1840) but added the genus Tunica (in this usage, a synonym of Petrorhagia, see Ball \& Heywood, 1964; Rabeler, 1984) to this list and divided these seven genera between two tribes: Diantheae and Lychnideae. Pax \& Hoffmann (1934) also accepted the tribe name Diantheae and added the genus Phrynella Pax \& K.Hoffm. to it in Die natürlichen Pflanzenfamilien. In Flora U.R.S.S. (Schischkin, 1936), the tribe Diantheae encompasses eight genera also including Acanthophyllum (divided into two subgenera: subg. Acanthophyllum and subg. Allochrusa (Bunge) Schischk.) and Kohlrauschia Kunth as well as Tunica in the sense of Petrorhagia. In other floristic works such as Flora Europaea (Tutin \& al., 1964), Flora of Turkey (Reeve $\&$ al., 1967) and Flora Iranica (Rechinger, 1988), the traditional subfamilial classification system (including three subfamilies: Illecebroideae Arn. [= Paronychioideae A.St.Hil ex Fenzl], Minuartioideae DC. [= Alsinoideae Beilschm.], Caryophylloideae Arn. [= Silenoideae Arn.]) has been applied to these genera, and Caryophylleae is assigned to subfamily Caryophylloideae.

There are relatively few monographs of genera of Caryophylleae. Bittrich (1993) provides the most recent comprehensive synopsis of the Caryophylleae, dividing the tribe into 17 genera. The monographic work on Gypsophila and its related genera (Barkoudah, 1962) has provided the primary source for determination of species in Gypsophila and Bolanthus. The genus Petrorhagia was revised by Ball \&
Heywood (1964), with Rabeler (1984) providing additional nomenclatural clarification. No recent monograph exists for Dianthus, with the most recent infrageneric classification appearing in Pax \& Hoffman (1934), or for Saponaria, with the only monograph published by Simmler (1910) and Shults (1989) providing additional information for taxa occurring in Russia.

Recent molecular phylogenetic studies on Caryophyllaceae have indicated the necessity for major changes in the classification of the family and rejected the subfamilial system, which has commonly been in use (Fior \& al., 2006; Harbaugh \& al., 2010; Greenberg \& Donoghue, 2011). Today, the family is divided into 11 tribes including Caryophylleae with Dianthus caryophyllus L. as type (Harbaugh \& al., 2010). Until now, 12 of the Caryophylleae genera accepted by Hernández-Ledesma $\&$ al. (2015) have been included in molecular analyses, but genera such as Gypsophila, Petrorhagia and Saponaria are poorly represented.

Gypsophila is one of the most heterogeneous and largest groups. The genus comprises approximately 150 species of annual or perennial herbaceous, creeping or cushion-forming plants, inhabiting primarily the mountainous steppes in the north temperate part of the Old World with a diversification hotspot in the Irano-Turanian region (Barkoudah, 1962; Amini \& al., 2011). These species also show major variation in inflorescence type ranging from many-flowered lax thyrses or panicles (e.g., G. elegans M.Bieb., G. paniculata L., G. pilosa Huds.) to compact head-like cymes (G. capitata M.Bieb., G. capituliflora Rupr., G. caricifolia Boiss.), and few-(uni-)flowered raceme-like monochasia (e.g., G. bazorganica Rech.f., G. saponarioides Bornm. \& Gauba). The morphological differences between Ankyropetalum Fenzl, Bolanthus, Gypsophila and Phrynella are minor (Table 2) and their delimitations appear artificial.

The main focus of the present study is to clarify the generic delimitation in Caryophylleae. The detailed aims of the study are: (1) to elucidate phylogenetic relationships and natural groupings in Caryophylleae, (2) to clarify the limits of the genera in the tribe, (3) to test the monophyly of Gypsophila and its closely related genera, and (4) to assess evolutionary progressions for morphological traits applied in former generic classifications of the tribe Caryophylleae.

\section{MATERIALS AND METHODS}

Taxon sampling. - This investigation is based primarily upon specimens deposited in the herbaria: B, G, LE, M, MSB and TUH. Over 2000 herbarium sheets of the representatives of Caryophylleae have been determined/revised and studied.

The present study is the largest phylogenetic study on the tribe in terms of both numbers of genera and species. Since the tribe itself was proven to be monophyletic in previous analyses with tribe Eremogoneae Rabeler \& W.L.Wagner or Sileneae as outgroup (Harbaugh \& al., 2010; Greenberg \& Donoghue, 2011), we included 12 representatives of the most 
Table 2. Characteristics of genera of Caryophylleae according to Bittrich (1993) and revisions proposed by Pirani \& al. (2014).

\begin{tabular}{|c|c|c|c|c|c|c|c|}
\hline & Gypsophila & Saponaria & Ankyropetalum & Pleioneura & Vaccaria & Acanthophyllum & Phrynella \\
\hline Type & G. repens L. & S. officinalis L. & $\begin{array}{l}\text { A. gypsophiloi- } \\
\text { des Fenzl }\end{array}$ & $\begin{array}{l}\text { Pl. griffithiana } \\
\text { (Boiss.) Rech.f. }\end{array}$ & $\begin{array}{l}\text { V. pyramidata } \\
\text { Medik. }\end{array}$ & $\begin{array}{l}\text { A. mucronatum } \\
\text { C.A.Mey. }\end{array}$ & $\begin{array}{l}\text { Ph. ortegioides } \\
\text { Pax \& K.Hoffm. }\end{array}$ \\
\hline $\begin{array}{l}\text { Chromosome } \\
\text { number }\end{array}$ & $\begin{array}{l}2 n=24,26,28, \\
30,34,36,48, \\
51,60,68\end{array}$ & $2 n=28,56$ & $2 n=26$ & - & $2 n=24,30$ & $\begin{array}{l}2 n=26,30, \\
60,90\end{array}$ & - \\
\hline No. of species & ca. 150 & ca. 30 & 4 & 1 & 1 & ca. $90-100$ & 1 \\
\hline Habit & $\begin{array}{l}\text { Annual and } \\
\text { perennial, some- } \\
\text { times densely } \\
\text { caespitose }\end{array}$ & $\begin{array}{l}\text { Perennial, } \\
\text { rarely annual } \\
\text { herbs }\end{array}$ & $\begin{array}{l}\text { Perennial, } \\
\text { densely caespi- } \\
\text { tose to densely } \\
\text { pulvinate }\end{array}$ & $\begin{array}{l}\text { Perennial } \\
\text { herbs with } \\
\text { thick rhizome } \\
\text { (geophyte) }\end{array}$ & $\begin{array}{l}\text { Annual glabrous } \\
\text { herbs }\end{array}$ & $\begin{array}{l}\text { Small, shrubby, } \\
\text { cushion-forming } \\
\text { perennials with } \\
\text { spiny leaves, or } \\
\text { rarely perennial } \\
\text { herbs }\end{array}$ & $\begin{array}{l}\text { Perennial herb } \\
\text { with woody } \\
\text { caudex, rigid } \\
\text { stem, }\end{array}$ \\
\hline Seed shape & Reniform & $\begin{array}{l}\text { Reniform to } \\
\text { almost globular }\end{array}$ & $\begin{array}{l}\text { Reniform- } \\
\text { globose, with } \\
\text { marginal hilum, } \\
\text { with granular } \\
\text { wrinkles }\end{array}$ & $\begin{array}{l}\text { Globular- } \\
\text { reniform, } \\
\text { compressed }\end{array}$ & $\begin{array}{l}\text { Reniform or } \\
\text { globose }\end{array}$ & $\begin{array}{l}\text { Obovoid- } \\
\text { reniform }\end{array}$ & $\begin{array}{l}\text { Oblong, comma- } \\
\text { shaped, with a } \\
\text { marginal hilum }\end{array}$ \\
\hline $\begin{array}{l}\text { Inflorescence } \\
\text { type/position }\end{array}$ & $\begin{array}{l}\text { Paniculate or } \\
\text { head-like cyme }\end{array}$ & $\begin{array}{l}\text { Lax or dense } \\
\text { paniculate or } \\
\text { capitate cymes, } \\
\text { rarely solitary }\end{array}$ & Lax cymes & Panicle cymes & $\begin{array}{l}\text { Inflorescence } \\
\text { terminal, regu- } \\
\text { larly dichasial, } \\
\text { lax, richly } \\
\text { branched }\end{array}$ & $\begin{array}{l}\text { Dichasial cymes } \\
\text { arranged in } \\
\text { terminal heads } \\
\text { and/or axillary } \\
\text { verticillasters, } \\
\text { sometimes } \\
\text { paniculate or } \\
\text { corymbose }\end{array}$ & $\begin{array}{l}\text { Dichasial inflo- } \\
\text { rescence very } \\
\text { often reduced to } \\
\text { solitary sessile } \\
\text { flowers }\end{array}$ \\
\hline Calyx & $\begin{array}{l}\text { Hemispherical, } \\
\text { campanulate, tur- } \\
\text { binate, or rarely } \\
\text { tubular, 5-nerved } \\
\text { with broad scari- } \\
\text { ous commissures, } \\
\text { 5-toothed }\end{array}$ & $\begin{array}{l}\text { Cylindrical, } \\
\text { obscurely } \\
\text { 15-25-veined }\end{array}$ & $\begin{array}{l}\text { Campanulate- } \\
\text { tubular, } \\
5 \text {-nerved with } \\
5 \text { small teeth }\end{array}$ & $\begin{array}{l}\text { Tubular, } \\
\text { 15-nerved, } \\
\text { 5-toothed }\end{array}$ & $\begin{array}{l}\text { Ovoid with } \\
5 \text { prominent } \\
\text { angles }\end{array}$ & $\begin{array}{l}\text { Tubular- } \\
\text { turbinate, } \\
\text { 5-15-nerved, } \\
\text { 5-toothed }\end{array}$ & $\begin{array}{l}\text { Long-campan- } \\
\text { ulate, up to about } \\
1 / 3 \text { divided in } \\
\text { teeth, } 5 \text {-costate, } \\
\text { the ribs alternat- } \\
\text { ing with hyaline } \\
\text { intervals }\end{array}$ \\
\hline Embryo & $\begin{array}{l}\text { (Circular) pe- } \\
\text { ripheral, central } \\
\text { endosperm, with } \\
\text { prominent radicle }\end{array}$ & $\begin{array}{l}\text { (Curved) pe- } \\
\text { ripheral, central } \\
\text { endosperm }\end{array}$ & $\begin{array}{l}\text { Peripheral; } \\
\text { endosperm } \\
\text { central }\end{array}$ & Curved & Curved & $\begin{array}{l}\text { Unciform or } \\
\text { strongly curved }\end{array}$ & $\begin{array}{l}\text { Hook-shaped, } \\
\text { with a straight } \\
\text { prominent radicle }\end{array}$ \\
\hline Petals & $\begin{array}{l}\text { Entire or slightly } \\
\text { emarginate }\end{array}$ & $\begin{array}{l}\text { Mostly dis- } \\
\text { tinctly clawed, } \\
\text { coronal scales } \\
\text { usually present }\end{array}$ & $\begin{array}{l}\text { Clawed, limb } \\
\text { 3(-5)-partite }\end{array}$ & $\begin{array}{l}\text { Pink, with nar- } \\
\text { rowly winged } \\
\text { claw, limb } \\
\text { entire, coronal } \\
\text { scales present }\end{array}$ & $\begin{array}{l}\text { 5, pink or } \\
\text { purple, clawed, } \\
\text { limb entire, den- } \\
\text { tate or notched, } \\
\text { coronal scales } \\
\text { absent }\end{array}$ & $\begin{array}{l}\text { Limb entire, } \\
\text { sometimes bifid, } \\
\text { gradually taper- } \\
\text { ing into claw }\end{array}$ & $\begin{array}{l}\text { Cuneate, with } \\
\text { a bare claw and } \\
\text { without corona }\end{array}$ \\
\hline Capsule & $\begin{array}{l}\text { Always exceed- } \\
\text { ing the calyx, } \\
\text { dehiscence }\end{array}$ & $\begin{array}{l}\text { Opening by } \\
4(6) \text { teeth }\end{array}$ & $\begin{array}{l}\text { Dehiscing from } \\
\text { base by irregu- } \\
\text { lar longitudinal } \\
\text { slits }\end{array}$ & $\begin{array}{l}\text { Capsule open- } \\
\text { ing by } 4 \text { teeth }\end{array}$ & $\begin{array}{l}\text { With papery } \\
\text { exocarp opening } \\
\text { by } 4 \text { teeth, en- } \\
\text { docarp dehisc- } \\
\text { ing irregularly }\end{array}$ & $\begin{array}{l}\text { 1- or 2-seeded, } \\
\text { mode of dehis- } \\
\text { cence various }\end{array}$ & $\begin{array}{l}\text { Long-ovoid, } \\
\text { opening with } 4 \\
\text { fissures extending } \\
\text { to the middle, } \\
\text { with } 1-3 \text { seeds }\end{array}$ \\
\hline Ovules number & $4-36$ & $2-14$ & $8-10$ & 12 & Numerous & $4(-21)$ & 8 \\
\hline Special features & - & $\begin{array}{l}\text { Seeds usually } \\
\text { smooth and } \\
\text { shiny }\end{array}$ & $\begin{array}{l}\text { Gynophore } \\
\text { absent, ovary } \\
\text { more or less } \\
\text { sessile }\end{array}$ & $\begin{array}{l}\text { Coronal scales } \\
\text { present }\end{array}$ & Seeds shiny & $\begin{array}{l}\text { Bracts and } \\
\text { leaves mostly } \\
\text { spiny }\end{array}$ & $\begin{array}{l}\text { Calyx with one } \\
\text { to four pairs of } \\
\text { bracteoles at base } \\
\text { (epicalyx) }\end{array}$ \\
\hline Distribution & $\begin{array}{l}\text { Temperate Eur- } \\
\text { asia, E Medi- } \\
\text { terranean, and } \\
\text { Irano-Turanian } \\
\text { region, Egypt, } \\
\text { Arabia, Somalia, } \\
\text { Australia }\end{array}$ & $\begin{array}{l}\text { Temperate } \\
\text { Eurasia, } \\
\text { chiefly in } \\
\text { Mediterranean } \\
\text { and Irano- } \\
\text { Turanian } \\
\text { region }\end{array}$ & $\begin{array}{l}\text { Turkey, Iran, } \\
\text { Iraq, Lebanon, } \\
\text { Syria, Palestine }\end{array}$ & $\begin{array}{l}\text { From C Asia to } \\
\text { W Himalaya; } \\
\text { Afghanistan }\end{array}$ & $\begin{array}{l}\text { C, E \& S } \\
\text { Europe; Asia }\end{array}$ & $\begin{array}{l}\text { C, W \& SW } \\
\text { Asia, Siberia }\end{array}$ & S \& C Turkey \\
\hline
\end{tabular}


Tabel 2. Continued.

\begin{tabular}{|c|c|c|c|c|c|c|c|}
\hline & Bolanthus & Petrorhagia & Velezia & Dianthus & Cyathophylla & Psammosilene & Diaphanoptera \\
\hline Type & $\begin{array}{l}\text { B. hirsutus } \\
\text { (Labill.) } \\
\text { Barkoudah }\end{array}$ & $\begin{array}{l}\text { P. saxifraga } \\
\text { (L.) Link }\end{array}$ & V. rigida $\mathrm{L}$. & $\begin{array}{l}\text { D. caryophyl- } \\
\text { lus } \mathrm{L} \text {. }\end{array}$ & $\begin{array}{l}\text { C. chlorifolia } \\
\text { (Poir.) Bocquet } \\
\text { \& Strid }\end{array}$ & $\begin{array}{l}\text { P. tunicoides } \\
\text { W.C.Wu \& } \\
\text { C.Y.Wu }\end{array}$ & $\begin{array}{l}\text { D. khorasanica } \\
\text { Rech.f. }\end{array}$ \\
\hline $\begin{array}{l}\text { Chromosome } \\
\text { number }\end{array}$ & $2 n=20,30$ & $\begin{array}{l}2 n=26,28 \\
30,60\end{array}$ & $2 n=28$ & $2 n=30,60,90$ & $2 n=30$ & $2 n=28$ & - \\
\hline No. of species & ca. 18 & ca. 33 & 2 & ca. 300 & 1 & 1 & 6 \\
\hline Habit & $\begin{array}{l}\text { Perennial, pu- } \\
\text { berulent to hirsute, } \\
\text { grey-green to } \\
\text { velvety herbs, with } \\
\text { thin short stems } \\
\text { and small leaves }\end{array}$ & $\begin{array}{l}\text { Annual and } \\
\text { perennial } \\
\text { herbs }\end{array}$ & $\begin{array}{l}\text { Annual, rigid, } \\
\text { dichotomously } \\
\text { branching herbs }\end{array}$ & $\begin{array}{l}\text { Annual or peren- } \\
\text { nial herbs, rarely } \\
\text { subshrubs }\end{array}$ & Annual herbs & $\begin{array}{l}\text { Perennial } \\
\text { puberulent } \\
\text { herbs }\end{array}$ & $\begin{array}{l}\text { Perennial and } \\
\text { tufted herbs, } \\
\text { woody at base }\end{array}$ \\
\hline Seed shape & $\begin{array}{l}\text { Comma-shaped, } \\
\text { compressed on } \\
\text { both sides, with } \\
\text { flat or channelled } \\
\text { back; testa with } \\
\text { small tubercles; } \\
\text { hilum marginal }\end{array}$ & $\begin{array}{l}\text { Peltate with } \\
\text { facial hilum }\end{array}$ & $\begin{array}{l}\text { Peltate with } \\
\text { facial hilum }\end{array}$ & $\begin{array}{l}\text { Peltate with } \\
\text { facial hilum }\end{array}$ & $\begin{array}{l}\text { Roundish, } \\
\text { reddish brown } \\
\text { to blackish, }\end{array}$ & Peltate & Reniform \\
\hline $\begin{array}{l}\text { Inflorescence type/ } \\
\text { position }\end{array}$ & $\begin{array}{l}\text { Contracted dicha- } \\
\text { sial cymes }\end{array}$ & $\begin{array}{l}\text { Panicles or } \\
\text { capitate cymes }\end{array}$ & $\begin{array}{l}\text { Solitary or } \\
\text { monochasial } \\
\text { cymes }\end{array}$ & $\begin{array}{l}\text { Solitary or } \\
\text { capitate terminal } \\
\text { cymes often sub- } \\
\text { tended by bracts }\end{array}$ & $\begin{array}{l}\text { Terminal heads } \\
\text { subtended by } \\
\text { bowl-shaped, } \\
\text { entire involucre }\end{array}$ & $\begin{array}{l}\text { Terminal } \\
\text { cymes }\end{array}$ & $\begin{array}{l}\text { Lax few-flow- } \\
\text { ered cymes }\end{array}$ \\
\hline Calyx & $\begin{array}{l}\text { Tubiform, pen- } \\
\text { tagonal, turbinate } \\
\text { at base, with small } \\
\text { teeth and with } 5 \\
\text { projecting ribs } \\
\text { alternating with } \\
\text { comparatively } \\
\text { broad hyaline } \\
\text { bands }\end{array}$ & $\begin{array}{l}\text { Cylindrical or } \\
\text { campanulate, } \\
\text { 5-toothed, } \\
\text { 5-15-nerved, } \\
\text { with scarious } \\
\text { commissures }\end{array}$ & $\begin{array}{l}\text { Tubular, usually } \\
(5-) 15 \text {-nerved, } \\
\text { without scarious } \\
\text { commissures, } \\
1-3 \text { bracts in } \\
\text { form of epicalyx } \\
\text { present }\end{array}$ & $\begin{array}{l}\text { Tubular with } \\
\text { many parallel } \\
\text { veins, without } \\
\text { membranous } \\
\text { commissures, } \\
\text { 5-toothed }\end{array}$ & $\begin{array}{l}\text { Cylindrical } \\
\text { with } 5 \text { short } \\
\text { teeth, without } \\
\text { scarious com- } \\
\text { missures and } \\
\text { commissural } \\
\text { veins }\end{array}$ & $\begin{array}{l}\text { Tubular, } \\
\text { 15-nerved, } \\
\text { 5-toothed }\end{array}$ & $\begin{array}{l}\text { Turbinate or } \\
\text { vase-shaped }\end{array}$ \\
\hline Embryo & $\begin{array}{l}\text { Hook-shaped, with } \\
\text { long prominent } \\
\text { radicle, peripheral }\end{array}$ & Straight & Straight & Straight & Curved & Straight & Curved \\
\hline Petal & $\begin{array}{l}\text { Entire, cuneate, } \\
\text { with small limb } \\
\text { and winged claw }\end{array}$ & $\begin{array}{l}5, \text { entire or } \\
\text { bifid, clawed } \\
\text { or not, coronal } \\
\text { scales absent }\end{array}$ & $\begin{array}{l}\text { 5(10), long- } \\
\text { clawed } \\
\text { with small } \\
\text { 2-4-toothed or } \\
\text { emarginated } \\
\text { limb, coronal } \\
\text { scales absent }\end{array}$ & $\begin{array}{l}\text { White, pink } \\
\text { or red, rarely } \\
\text { yellow, limb } \\
\text { entire, toothed or } \\
\text { fimbriate, without } \\
\text { coronal scales, } \\
\text { claw long, with } \\
\text { two longitudinal } \\
\text { ridges }\end{array}$ & $\begin{array}{l}\text { Linear oblong, } \\
\text { inconspicuous }\end{array}$ & $\begin{array}{l}\text { 5, purple- } \\
\text { violet, incon- } \\
\text { spicuously } \\
\text { clawed, entire }\end{array}$ & $\begin{array}{l}5, \text { rose or } \\
\text { violet, entire or } \\
\text { emarginate }\end{array}$ \\
\hline Capsule & $\begin{array}{l}\text { Longer than se- } \\
\text { pals, with } 4 \text { teeth }\end{array}$ & $\begin{array}{l}\text { Opening by } \\
4 \text { teeth }\end{array}$ & $\begin{array}{l}4 \text { teeth splitting } \\
\text { into } 2 \text { valves }\end{array}$ & $\begin{array}{l}\text { Opening by } \\
4 \text { teeth }\end{array}$ & $\begin{array}{l}\text { Opening by } \\
4 \text { teeth }\end{array}$ & $\begin{array}{l}\text { Membranous, } \\
\text { probably } \\
\text { indehiscent, } \\
\text { 1-seeded }\end{array}$ & 4-valved \\
\hline Ovules number & $8-20$ & Numerous & Few & Numerous & Unknown & 2 & $(6-) 8-19$ \\
\hline Special features & $\begin{array}{l}\text { Seeds smooth and } \\
\text { shiny }\end{array}$ & $\begin{array}{l}\text { Leaves nar- } \\
\text { row, grass-like }\end{array}$ & $\begin{array}{l}\text { Sepal hardened } \\
\text { at the apex and } \\
\text { margin }\end{array}$ & $\begin{array}{l}\text { Epicalyx scales } \\
\text { two to many }\end{array}$ & $\begin{array}{l}\text { Bowl-shaped } \\
\text { involucre } \\
\text { subtending } \\
\text { inflorescence }\end{array}$ & $\begin{array}{l}\text { Nearly non- } \\
\text { splitting, } \\
1 \text {-seeded and } \\
\text { membranous } \\
\text { in texture }\end{array}$ & $\begin{array}{l}\text { Inflated calyx, } \\
\text { winged at ribs, } \\
\text { caespitose } \\
\text { woody cushions }\end{array}$ \\
\hline Distribution & $\begin{array}{l}\text { Greece, S Turkey, } \\
\text { Syria, Lebanon, } \\
\text { Palestine }\end{array}$ & $\begin{array}{l}\text { Europe, from } \\
\text { Mediterranean } \\
\text { to Kashmir, } \\
\text { and on Canary } \\
\text { Islands }\end{array}$ & $\begin{array}{l}\text { Sino-Himalaya, } \\
\text { and from the } \\
\text { Mediterranean } \\
\text { east to } \\
\text { Afghanistan }\end{array}$ & $\begin{array}{l}\text { Europe, Asia, } \\
\text { especially } \\
\text { Mediterranean, } \\
\text { Africa }\end{array}$ & $\begin{array}{l}\text { Mountains of } \\
\text { Greece and } \\
\text { Turkey }\end{array}$ & $\begin{array}{l}\text { China, prov. } \\
\text { Yunnan }\end{array}$ & $\begin{array}{l}\text { High altitude } \\
\text { of NE Iran, } \\
\text { Turkmenistan, } \\
\text { and Afghanistan }\end{array}$ \\
\hline
\end{tabular}


closely related tribes to Caryophylleae (i.e., Alsineae Lam. \& DC., Arenarieae Kitt., Eremogoneae and Sileneae) in our analyses in order to keep the effect of sequence homoplasy on tree reconstruction at minimum. In general, six species of different clades known in Silene L. (Sileneae), one species each of Cerastium L. and Stellaria L. (Alsineae), two species of Eremogone Fenzl (Eremogoneae), one species each of Arenaria and Moehringia L. (Arenarieae) were selected as outgroups according to the results of previous molecular phylogenetic studies (Harbaugh \& al., 2010; Greenberg \& Donoghue, 2011). Within the tribe, we tried to perform a balanced sampling representing almost all major morphological lineages known to us based on personal experience and examining pertinent literature. Therefore, the present study allows us to define the genera in Caryophylleae more appropriately, matching morphological, geographical and molecular phylogenetic evidence.

We produced a dataset of nrDNA ITS with 136 (59 new sequences and 77 obtained from GenBank) accessions representing 112 species, and a dataset of cpDNA rps 16 with 94 (58 new sequences and 36 obtained from GenBank) accessions representing 85 species. Dissatified with the poor sampling of Gypsophila in previous molecular phylogenetic studies, we focused more intensively on this genus, and generated sequences for 44 and 34 species of this genus for nrDNA ITS and cpDNA rps16, respectively. For this purpose we attempted to sample all subgenera and sections recognized in Barkoudah (1962). Representatives of four formerly recognized genera of Caryophylleae, i.e., Ankyropetalum, Bolanthus, Cyathophylla Bocquet \& Strid, and Phrynella as well as the new genera described in this paper, i.e. Balkana gen. nov., Graecobolanthus gen. nov., were sequenced in this study for the first time. The voucher specimens for the sequences generated in this study (Appendix 1) are deposited in B, M, MSB and/or TUH.

DNA extraction, amplification and sequencing. - The present study was performed based on two molecular markers, one nuclear: the internal trascribed spacer (ITS) region of the ribosomal cistron (consisting of ITS1, the intervening 5.8S gene, and ITS2) and one plastid intron: rps16. DNA was extracted from dried leaf material using a NucleoSpin Plant DNA extraction kit (Macherey-Nagel, Düren, Germany) according to the manufacturers' protocol. Amplification of the ITS region was performed using the primer pair Leul (Vargas $\&$ al., 1998) and ITS4 (White \& al., 1990). In some difficult cases ITS 2 and ITS 3 were used, as described by White $\&$ al. (1990). For the plastid region (complete intron rps16), we used the primers rpsF and rpsR2R or rpsF and rpsR3R (Oxelman \& al., 1997; Petri \& Oxelman, 2011; Kool \& al., 2012). All PCR amplifications were performed in a Thermocycler T-Personal 48 (Biometra, Göttingen, Germany), Primus 96 plus (MWG: Biotech, Ebersberg, Germany), or 2720 (Applied Biosystems, Carlsbad, California, U.S.A.).

Cycle sequencing was done using BigDye Terminator v.3.1, Cycle Sequencing Kit (Applied Biosystems). DNA samples were sequenced with ABI3730 DNA Analyser 48well capillary sequencer (Applied Biosystems).
Alignment and tree reconstruction. - We edited the sequences with Geneious v.8.0.5 (Kearse \& al., 2012), and conducted the multiple alignment using MAFFT v.7 with default parameters (Katoh \& Standley, 2013). The alignments were manually corrected using Mesquite v.3.02 (Maddison \& Maddison, 2011).

Alignments of the present phylogenetic datasets are available as supplementary material (https://doi.org/10.12705/671.6.S). The beginning and end of the alignments, where the sequences of many individuals lack sharp electropherogram peaks, were trimmed prior to analysis. The ITS and rps16 datasets were analyzed separately as their taxon composition differed. Two kinds of analyses were run on each dataset separately: Bayesian inference (BI) and maximum parsimony (MP). Before running BI, the optimal substitution models were estimated using the Akaike information criterion (AIC) in jModelTest v.0.1.1 (Posada, 2008). General time reversible model with gammashaped rate variation and a proportion of invariable sites $(\mathrm{GTR}+\mathrm{I}+\Gamma)$ was estimated as the best-fit model for both ITS and rps 16 markers. For BI we used MrBayes v.3.2.6 (Ronquist \& Huelsenbeck, 2003) under CIPRES server (Miller \& al., 2010) with the number of MCMC generations for ITS and rps16 datasets set to 40 million. Trees were sampled every 1000 generations with the default of three "heated" and one "cold" chain, and pre-stationarity MCMC samples were discarded as burn-in (2500 samples as calculated by Tracer v.1.6 software, Rambault \& al., 2014). The remaining trees were summarized in a $50 \%$ majority-rule consensus tree for each dataset. MP analyses were performed using PAUP* v.4.0b10 (Swofford, 2003) with the following parameters: all characters unordered and equally weighted, heuristic search with random sequence addition, tree-bisection-reconnection branch swapping, 50 random-addition-sequence replicates, and MAXTREES option set to 10,000 . The obtained trees were summarized in a strict consensus tree. Bootstrapping was done using maximum likelihood method as implemented in RAxML-HPC2 on XSEDE v. 8 (Stamatakis, 2014) the following settings: model = GTRCAT, bootstrap nreps $=1000$ (summarized in a 50\% majority-rule consensus tree as a cladogram).

Morphological character mapping. - A data matrix of four morphological characters for all taxa included in the phylogenetic analysis of ITS was prepared. The selected characters were: (1) membranous commissures of calyx (present/ absent), (2) bracteoles (present/absent), (3) seed shape (reniform or pyriform/reniform-oblong/peltate/comma shaped), and (4) embryo shape (curved/straight/hook-shaped). The evolutionary pathways were reconstructed using Mesquite v.3.02 (Maddison \& Maddison, 2011). We employed the Markov $k$-state 1 (Mk1) parameter model of evolution for the ML reconstructions, with equal probability for any particular character change.

Typification information. - Details about type specimens of the basionyms of the new combinations and resurrected names that we have included are based on examining protologues and searching major indices (Tropicos, http://www. tropicos.org/; JSTOR Global Plants, https://plants.jstor.org), as well as websites of several individual herbaria (BM, BR, E, 
G, GH, K, KEW, L, LINN, OS, P, US, WU) for extant specimens. We have examined a digital image from one (or more) of these sources for any specimen where we cite a barcode in the type citations.

\section{口 RESULTS}

The alignment of the ITS dataset needed introduction of ten large indels ( $\geq 5 \mathrm{bp}$ ). The final ITS matrix for 135 terminals comprised a total of 700 characters, whereas the rps 16 dataset with 94 terminals was finally 1034 bp long and included 29 large indels. A list of alignment characteristics and parsimony statistics is presented in Table 3 . The results of MP and BI for both datasets were congruent. Therefore, we present and discuss only the $50 \%$ majority-rule trees obtained from BI of the ITS (Fig. 2) and rps16 (Fig. 3). For a better comparison of the obtained trees and checking for congruency between the two datasets, the mirror image of obtained trees is shown in Fig. 4.

All trees are congruent in showing tribe Caryophylleae as monophyletic with Silene (in rps16 trees) or Eremogone (in ITS trees) as sister group. We recognize three main clades in both trees which are called Gypsophilinae, Saponaria s.str. and Caryophyllinae. In the ITS tree (Fig. 2), Psammosilene W.C.Wu \& C.Y.Wu, missing in the rps 16 tree, is sister to these three. The largest clade in the tribe in terms of species number is Caryophyllineae and can be subdivided into four clades: (1) Acanthophyllum s.l. (incl. Allochrusa, Diaphanoptera); (2) Cyathophylla (including Cyathophylla spp., Saponaria viscosa C.A.Mey. and a few species placed in Gypsophila by Barkoudah, 1962); (3) Dianthus s.l. (including Bolanthus spp., Phrynella ortegioides (Fisch. \& C.A.Mey.) Pax \& K.Hoffm., Gypsophila confertifolia, Petrorhagia spp., Psammophiliella spp., G. spergulifolia Griseb., Dianthus spp., and Velezia rigida); and (4) Petroana (including Gypsophila montana and G. montserratii). Gypsophilinae and Saponaria s.str. show a sister relationship in the rps16 tree, and their clade is in turn sister to Caryophyllinae, while Saponaria s.str. forms the sister to the Caryophyllinae in the ITS topology (Fig. 2). The Gypsophilinae clade embraces most species of Gypsophila including the type of the genus (G. repens L.) along with the representatives of the genera Vaccaria, Ankyropetalum, and Bolbosaponaria Bondarenko as well as one species of Diaphanoptera (D. afghanica Podlech).

\section{DISCUSSION}

Despite many molecular phylogenetic studies in Caryophyllaceae during recent years (Fior \& al., 2006; Harbaugh \& al., 2010; Greenberg \& Donoghue, 2011; Pirani \& al., 2014; Dillenberger \& Kadereit, 2014; Sadeghian \& al., 2015) the generic boundaries in the tribe Caryophylleae are still blurred (Pirani \& al., 2014; Hernández-Ledesma \& al., 2015). The scanty sampling of some large genera in the tribe, such as Gypsophila and Saponaria, as well as missing sequences of some smaller genera and little knowledge of the morphology of many crucial taxa are the main reasons for this uncertainty. Since many ornamental and medicinal plants are representatives of this tribe, and due to frequent occurrence of the members of this tribe in natural ecosystems in SW Asia, providing the correct taxonomic name to these taxa is very important, though challenging.

The general topology of the trees obtained here supports the presence of three major clades in Caryophylleae, fitting partly with the subtribal system proposed by Šourková (1978). Our phylogenies suggest adding two subtribes to subtribes Dianthinae Šourková (homotypic synonym of Caryophyllinae (Juss.) Rabeler \& Bittrich, see Rabeler \& Bittrich, 1993) and Gypsophilinae Šourková, namely subtribes Saponariinae and Psammosileninae. However, as three of the four subtribes would each include only one genus, this system seems unnecessary. Therefore, we prefer to name not all clades formally as shown on the trees (Figs. 2-4). According to the results we obtained, we provide below a detailed survey on the delimitation of genera in tribe Caryophylleae.

Gypsophila. - As circumscribed currently, this is a heterogeneous group morphologically (Bittrich, 1993). Our study shows that a major revision is necessary to make this genus monophyletic. All analyses conducted here show clearly that the generic names Ankyropetalum, Bolbosaponaria (already included in the genus, see Bittrich, 1993), Dichoglottis Fisch. \& C.A.Mey. (already included in the genus, see Barkoudah, 1962), Vaccaria and one species of Diaphanoptera (D. afghanica) are nested within Gypsophila. In each of these cases, the morphological diagnostic features are shared by certain species assigned to Gypsophila. In the case of Ankyropetalum the deeply incised petals as well as exserted stamens (in addition to other features mentioned by Barkoudah, 1962) might represent autapomorphies. The membranous commissures and the winged veins of the calyx as well as its inflated form in Vaccaria are also evident in Diaphanoptera khorasanica Rech.f. and partly in D. afghanica as well as Bolbosaponaria bucharica (B.Fedtsch.) Bondarenko (also nested within Gypsophila in our analyses). The possible inclusion of Vaccaria in Gypsophila has been suggested before (Kadereit \& al., 2016). The genus Diaphanoptera is clearly polyphyletic with three species

Table 3. Alignment characteristics and statistics of phylogenetic analyses of rps 16 and ITS datasets in Caryophylleae.

\begin{tabular}{lll}
\hline & rps 16 & ITS \\
\hline Number of terminals & 94 & 135 \\
Sequence length [bp] & $414-810$ & $242-648$ \\
Aligned length [bp] & 1034 & 700 \\
Constant characters [bp] & 541 & 261 \\
Parsimony-uninformative characters [bp] & 158 & 82 \\
Parsimony-informative characters [bp] & 335 & 357 \\
Parsimony-informative characters [\%] & 32.4 & 51 \\
\hline
\end{tabular}




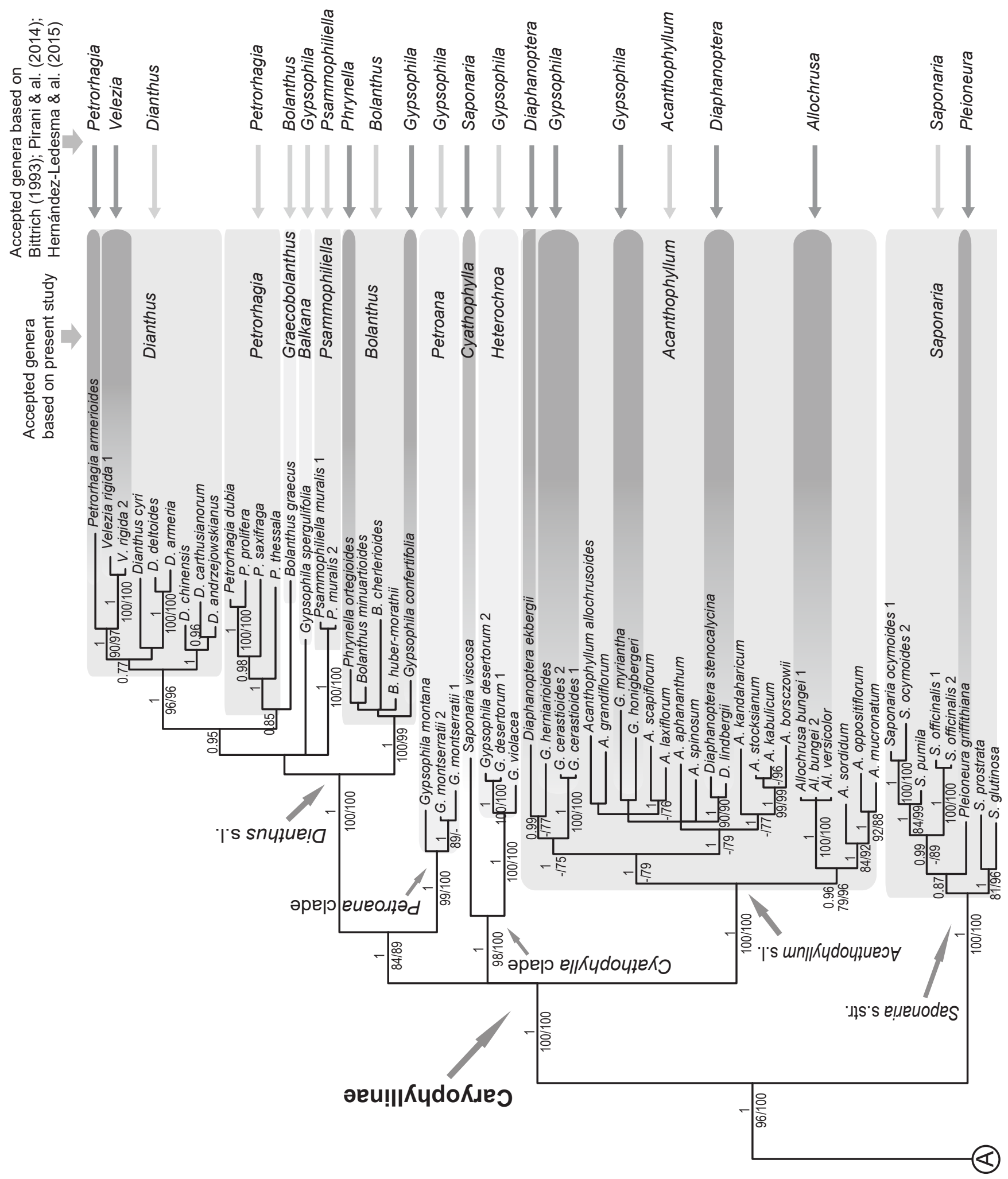

Fig. 2. Majority-rule consensus tree inferred from Bayesian analysis of ITS data in tribe Caryophylleae. Numbers above the branches indicate posterior probability values; those below branches are MP/ML bootstrap values. The generic names inside the grey boxes are those accepted in the present study. Species names are according to www.ipni.org and do not follow the taxonomic treatments suggested in the present study. The generic names in the column right to the grey area are those accepted by Bittrich (1993), Pirani \& al. (2014), and Hernández-Ledesma $\&$ al. (2015). Values below 0.5 for posterior probability and below 50\% for ML/MP bootstrap are not shown. 
that are woody at base nested within Acanthophyllum (see also Pirani \& al., 2014) and one species in Gypsophila. In line with previous analyses, the genus Diaphanoptera cannot be maintained and should be reduced to a synonym under Acanthophyllum (Pirani \& al., unpub. data). It seems that the unique tuberous roots and long tubular calyces with membranous commissures between the calyx veins in Bolbosaponaria are not applicable at generic rank, but may be useful for separating lower ranks such as sections. However, the subgeneric classification of Gypsophila needs a richer sampling and is not addressed here, but it is included in the scope of our future investigations.

Another important finding of our study relating to Gypsophila is the necessity to exclude some morphologically aberrant taxa. Such a treatment has already been applied to $G$. muralis L. and three related taxa now considered as Psammophiliella Ikonn. (Hernández-Ledesma \& al., 2015: based on results obtained by Greenberg \& Donoghue, 2011, and Pirani \& al., 2014). Our results show that Gypsophila violacea (Ledeb.) Fenzl, G. desertorum (Bunge) Fenzl, G. montserratii Fern.Casas, G. montana Balf.f., G. spergulifolia, G. confertifolia Hub.-Mor., G. cerastioides D.Don, G. herniarioides Boiss., G. honigbergeri (Fenzl) Boiss. and G. myriantha Rech.f. should also be transferred to other genera.

The last four species listed above are placed in the Acanthophyllum s.l. clade. Gypsophila cerastioides is neither spiny nor shows the typical many-flowered rich axillary inflorescences known in most species of Acanthophyllum.

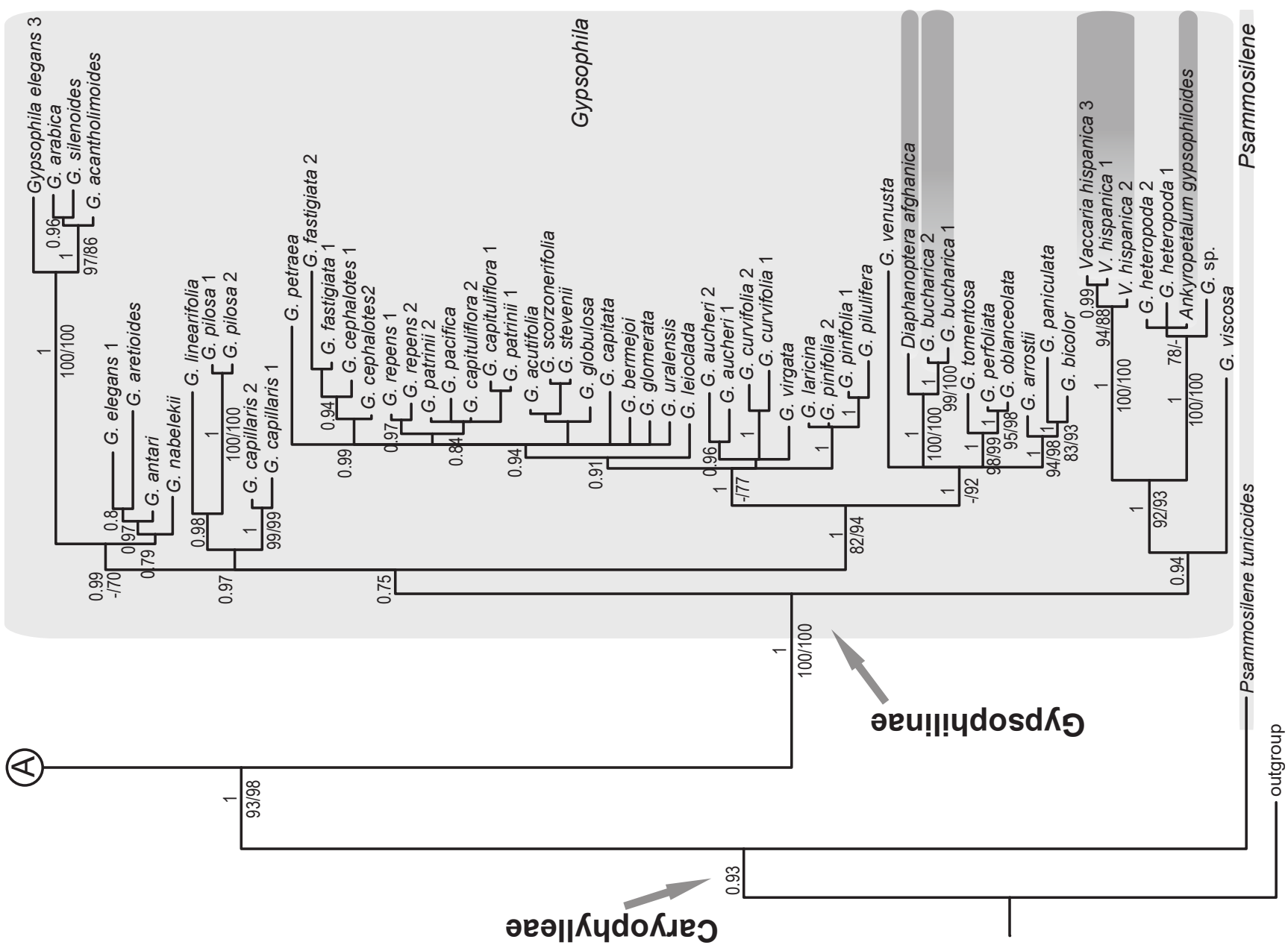


The broad leaves, many-ovulate capsules and large petals in this species indicate rather its unique position that led some earlier taxonomists to assign it to the genus Acosmia Benth. (or Timaeosia Klotzsch). In the ITS tree presented here, this species is closely related to Diaphanoptera ekbergii Hedge \& Wendelbo, and G. herniarioides.

In line with our molecular phylogenetic results, the woody cushion-forming habit, the well-developed short lateral branches in $G$. herniarioides resulting in a false verticillate phyllotaxy as well as dense and many-flowered corymbose inflorescences, and 4- to 12-ovulate ovary fit well with Acanthophyllum, but are absent or rarely observed in Gypsophila. However, the Acanthophyllum s.l. clade includes some other unarmed plants such as members of Allochrusa, and therefore, recognition of neither $G$. herniarioides nor Allochrusa spp. under separate genera are supported by molecular data (see also Pirani \& al., 2014). Our extended taxon sampling (especially regarding the number of genera sampled) for both markers, does not allow Allochrusa to be separated from Acanthophyllum. The species of the genus Allochrusa were considered once as members of Acanthophyllum subg. Allochrusa (Schischkin, 1936) and our molecular phylogenetic studies corroborate the taxonomic treatment performed by Pirani \& al. (2014) and contradict the treatment by HernándezLedesma \& al. (2015) where it was recognized provisionally at the generic level. According to this concept, it is necessary to resurrect the generic name Acanthophyllum for some taxa treated as Allochrusa in recent taxonomic surveys (see under Taxonomic implications).

Gypsophila honigbergeri is spiny (at least at leaf apex) and shows characteristic capsules of Acanthophyllum (low ovule number, one-seeded), and was suggested previously to be a member of this genus (Barkoudah, 1962). Aggregation of some characters, i.e., cylindrical calyx, shortly exserted petals and long stamens, which are unusual characters in Gypsophila, associated with a cushion-forming habit resembling Acanthophyllum drove Rechinger (1988) to describe the distinct subgenus Kabulianthe under Gypsophila. Ikonnikov (2004) even elevated this taxon to generic rank and introduced the combination Kabulianthe honigbergeri (Fenzl) Ikonn.

Gypsophila myriantha is also spiny and similar to Acanthophyllum in general habit except for the open paniculate inflorescence that is similar to many species of Gypsophila. The capsules in this species have not been seen, but the number of ovules is lower than 12, associating it again with Acanthophyllum. Our molecular phylogenetic investigations clearly place this species in Acanthophyllum.

Gypsophila desertorum and $G$. violacea form a distinct clade sister to Acanthophyllum s.1.+Dianthus s.l. clades. Both species are representatives of Gypsophila sect. Heterochroa
(Bunge) A.Braun (for notes on correct name and typification of this taxon see Rabeler, 1993) and show a south to east Siberian distribution. Among the species Barkoudah originally assigned to G. sect. Heterochroa, G. cerastioides and G. hernarioides, should be transferred to Acanthophyllum and are restricted to Afghanistan and Pakistan (see above), while other species show a more northern distribution reaching Far East and Central Asia. This latter group including G. antoninae Schischk., G. desertorum, G. microphylla (Schrenk) Fenzl, G. sericea (Ser.) Krylov (三 Heterochroa petrea Bunge: type of the genus Heterochroa), G. turkestanica Schischk. and $G$. violacea are low herbaceous plants with short internodes, small leaves, short pedicels and short campanulate calyces with calyx teeth mostly scarious at margins, and lack calcium oxalate crystals (which are present in most species of Gypsophila: Barkoudah, 1962). Our phylogenetic results, in accordance with geographical distribution patterns and morphology, suggest resurrection of the genus Heterochroa Bunge similar to Gypsophila sect. Heterochroa as defined by Barkoudah (1962) but excluding G. cerastioides, G. hernarioides and $G$. honigbergeri that should be transferred to Acanthophyllum. No material of G. glandulosa (Boiss.) Walp. was available to us; a species distributed in Turkey showing intermediate morphological characters between Heterochroa, Gypsophila and Acanthophyllum.

Gypsophila montserratii and G. montana (E Saponaria montana (Balf.f.) Barkoudah) are characterized by a very small calyx and petals. The haploid base chromosome number is known only for the former ( $x=13$ : Löve, 1973), which is neither congruent with Gypsophila (mostly $x=17$ ) nor with Dianthus $(x=15)$. They form a highly supported clade sister to the Dianthus s.l. clade in the ITS and rps16 trees (Figs. 2, 3). Like Miller \& Cope (1996), who treated G. montana within Gypsophila, we were not able to trace any important morphological character that supported Barkoudah (1962) transferring $G$. montana to Saponaria, but the morphological resemblance of this taxon to $G$. montserratii is strong enough to correlate it with the latter. These two species are geographically remote from each other: $G$. montserratii is known from the Iberian Peninsula, and G. montana is distributed in mountains and wadi-beds of Socotra (an archipelago in Arabian Sea, territory of Yemen) (Miller \& Cope, 1996). In line with our molecular phylogenetic analyses and morphological evidence, we suggest describing a new genus, Petroana, for this group (see below under Taxonomic implications).

Saponaria. - Seven species of Saponaria are included in our analyses, most of which form a clade in both analyses that includes Pleioneura griffithiana (Boiss.) Rech.f. Although the Saponaria clade is fully supported in the analyses of both markers, its placement varies between the markers used (see under

\footnotetext{
Fig. 3. Majority-rule consensus tree inferred from Bayesian analysis of rpsl6 data in tribe Caryophylleae. Numbers above the branches indicate posterior probability values; those below branches are MP/ML bootstrap values. Species names are according to www.ipni.org and do not follow the taxonomic treatments suggested in the present study. The generic names inside the grey boxes are those accepted in the present study. The generic names in the column right to the grey area are those accepted by Bittrich (1993), Pirani \& al. (2014), and Hernández-Ledesma \& al. (2015). Values below 0.5 for posterior probability and below 50 for ML/MP bootstrap are not shown.
} 


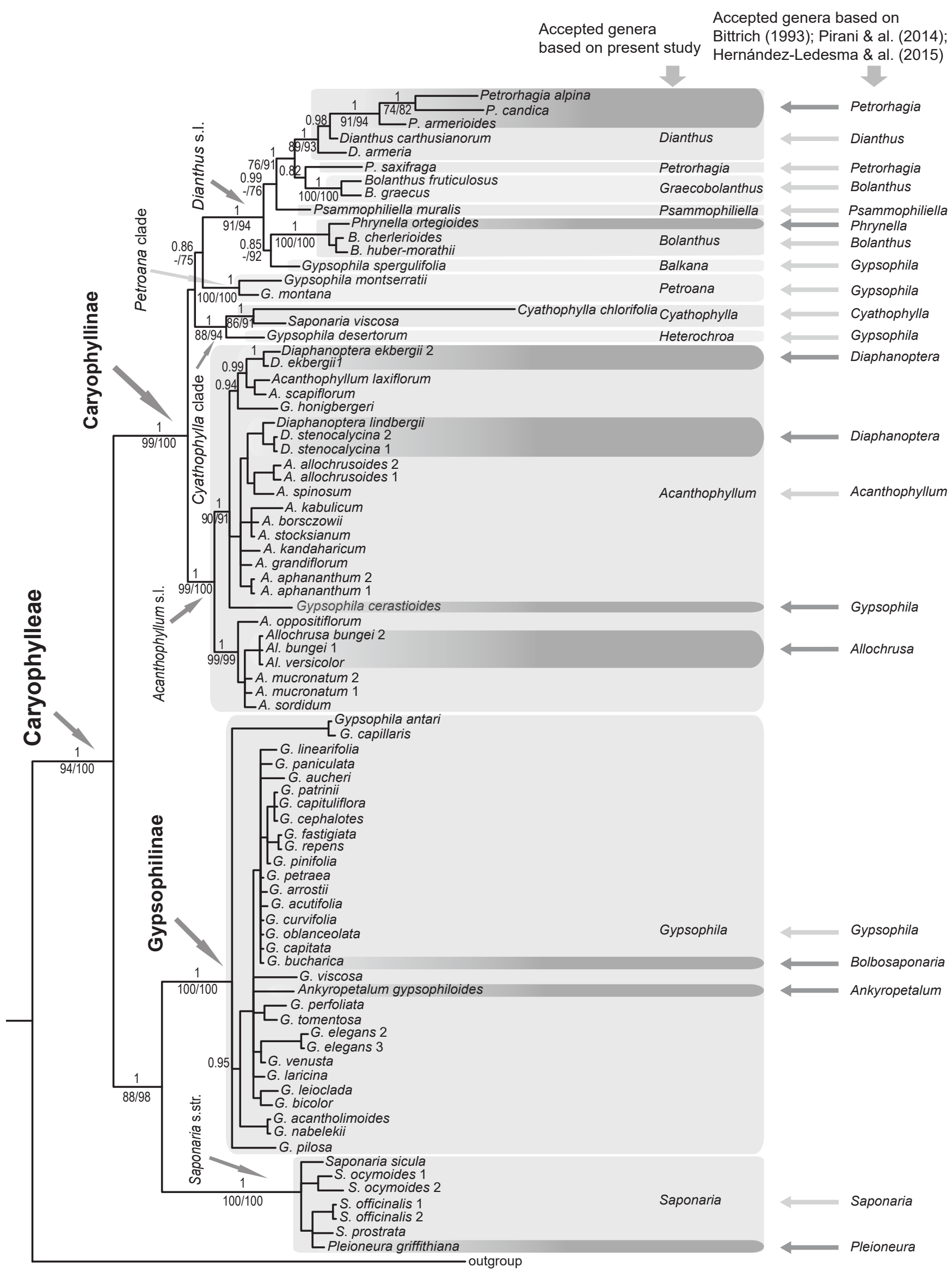


Results). Our results show clearly that Pleioneura is nested within Saponaria in spite of the unique stigma (positioned just at the end of the style) and the membranous commissures between the calyx veins. In contrast to Bittrich (1993) and Hernández-Ledesma \& al. (2015), who recognized Pleioneura, we suggest its synonymy within Saponaria.

Among the species currently assigned to Saponaria, S. viscosa is nested within the Cyathophylla clade (Fig. 3). Unfortunately, the ITS sequence for Cyathophylla chlorifolia Bocquet \& Strid could not be generated, but the rps16 sequences put $C$. chlorifolia and $S$. viscosa together clearly with full support. The perfoliate leaves and congested inflorescence in Cyathophylla are the most important morphological features separating it from Saponaria. However, the pedicels in $S$. vis$\cos a$ are relatively short, so that the young inflorescences do show a congested form. In general, only the ovate to rounded leaves in $C$. chlorifolia, which look perfoliate at the base, can be considered as important characters separating these taxa. Furthermore, C. chlorifolia is found in Greece and Turkey, whereas $S$. viscosa is distributed in eastern Turkey, Azerbaijan, Iraq, Iran and Turkmenistan. The distribution of these species overlaps somewhat in Ankara Province in Turkey.

Dianthus s.I. - Bolanthus, Dianthus, Petrorhagia, Phrynella, Psammophiliella, and Velezia are the main representatives of the clade Dianthus s.l.; our study is the first molecular investigation including genera Bolanthus and Phrynella. Furthermore, we extended the sampling of Petrorhagia, supporting its paraphyly as previously indicated but based on a different grouping of sampled taxa (Greenberg \& Donoghue, 2011). The relatively rich sampling of Dianthus in previous analyses (Valente \& al., 2010; Greenberg \& Donoghue, 2011) indicated that Dianthus was monophyletic with Velezia nested within (Harbaugh \& al., 2010; Kemler \& al., 2013). Despite low sampling here, our analyses also suggest inclusion of Velezia as well as a few species of Petrorhagia (excluding its type: P. saxifraga (L.) Link) in Dianthus.

Petrorhagia. - Morphologically, species of Petrorhagia either have conspicuous bracts encircling the calyx (including the type) or such bracts are missing. Our analyses clearly suggest including this latter group in Dianthus; most of these species have in the past been placed within Gypsophila (Grisebach, 1843).

In both trees (Figs. 2, 3) the Dianthus s.l. clade is divided into five main lineages with unresolved or moderately to low-supported relationships: (1) Bolanthus core group including some species of this genus as well as Gypsophila confertifolia and Phrynella; (2) Psammophiliella muralis; (3) G. spergulifolia; (4) the core group of Petrorhagia (including its type) along with the second group of Bolanthus (B. graecus, B. fruticulosus); and (5) Dianthus, Velezia and the second group of Petrorhagia (including $P$. armerioides, $P$. alpina and P. candica).

The findings of our analyses indicate that a group of species currently assigned to Petrorhagia sect. Pseudotunica (Fenzl) Post \& Kuntze and sect. Pseudogypsophila (A.Braun) P.Ball \& Heywood, which are characterized by the absence of conspicuous epicalyx bracts, are also associated with Dianthus and form a common clade with Velezia. Since Dianthus sect. Armeriastrum Ser. forms the most basally branching clade of the genus (as currently circumscribed, see Valente \& al., 2010) and the clade composed of Velezia rigida and part of $P$. sect. Pseudotunica are sister to the Dianthus crown group, it seems that it is inevitable to extend the formerly suggested lumping approach to place $P$. sect. Pseudotunica in Dianthus. However, as the type of this section was not available to us, the formal synonymy of this section should wait for further investigations, but the few species of this section analyzed here are transferred to Dianthus (see under Taxonomic implications).

Bolanthus. - Bolanthus fruticulosus and B. graecus are both distributed in Greece (Strid, 1986) slightly disjunct from most species of the genus, which is known from Turkey and Middle East. The representatives of the genus from both areas are mostly saxicolous plants with showy petals rounded at the apex as well as conspicuous calyx veins and narrow commissural membranes. However, the petals in the Greek species turn abruptly downwards and become clearly deflexed shortly after anthesis, while in species from Turkey and the Middle East the petals might be recurved, but not abruptly deflexed. Our results agree with this morphological characteristic and geographical data, suggesting a new genus for the Greek representatives formerly assigned to Bolanthus is needed (see Graecobolanthus under Taxonomic implications).

Gypsophila confertifolia, which shows an overlapping distribution pattern with the main group of Bolanthus centered in the East-Mediterranean phytogeographic subregion (sensu Eig, 1931), is characterized by a tubular calyx and short pedicels, which give rise to capitate inflorescences, resembling some species of Bolanthus such as B. minuartioides (Jaub. \& Spach) Hub.-Mor. The main difference between this species and members of Bolanthus is its annual habit. Our ITS trees (Fig. 2) suggest that this species is more closely related to Bolanthus rather than Gypsophila or, as suggested by Ikonnikov (1976), Psammophiliella. This assumption is also supported by geographical and morphological data. Based on available data, G. confertifolia should be transferred to Bolanthus.

A similar situation involves the obligate serpentinophyte taxon (Marin \& Tatić, 2001; Jakovljević \& al., 2011) G. spergulifolia. Morphologically this species is characterized by a basal aggregate of linear leaves, which are triangular in cross-section,

Fig. 4. Tanglegram of Dendroscope program package (Huson \& Scornavacca, 2012) comparing the phylogenies of ITS (left side) and rps16 datasets (right side) based on the $50 \%$ majority-rule consensus trees obtained from Bayesian phylogenetic analyses. Numbers above the branches indicate posterior probability values; those below branches are MP/ML bootstrap values. Values below 0.5 for posterior probability and below 50\% for ML/MP bootstrap are not shown. Grey boxes represent same genera of Caryophylleae as mentioned in the key at the bottom right of the figure. 


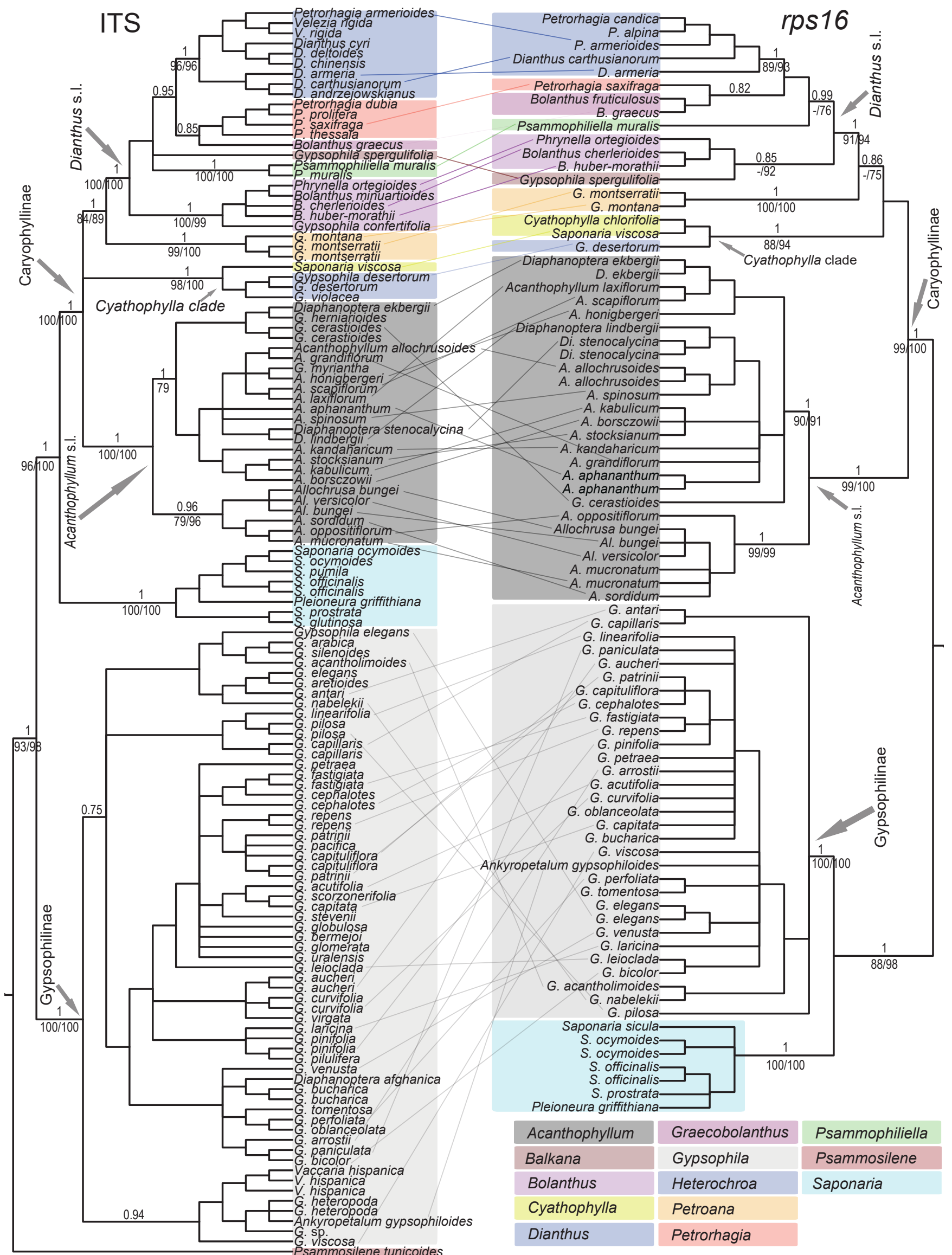


relatively long pedicels and a short campanulate-turbinate calyx. Furthermore, the petals are uniquely bicolored, red on the outer surface, but with a white or pink inner surface. It shows also an isolated geographic distribution, endemic to the Balkan region (in Albania and Serbia). Our results suggest recognizing this taxon as distinct from both Bolanthus and Gypsophila (see Balkana under Taxonomic implications), although the commissural membranes of the calyx known in both genera occur also in this taxon. In our phylogenetic trees this species is placed more closely to Bolanthus rather than to Gypsophila.

Phylogenetic analyses of both markers clearly place Phrynella within Bolanthus. Morphological and geographical data also support this relationship. The monotypic genus Phrynella is known only from Turkey, where several species of Bolanthus are also found, sometimes in similar regions (Reeve \& al., 1967). Short internodes, 1- to 3-flowered

A
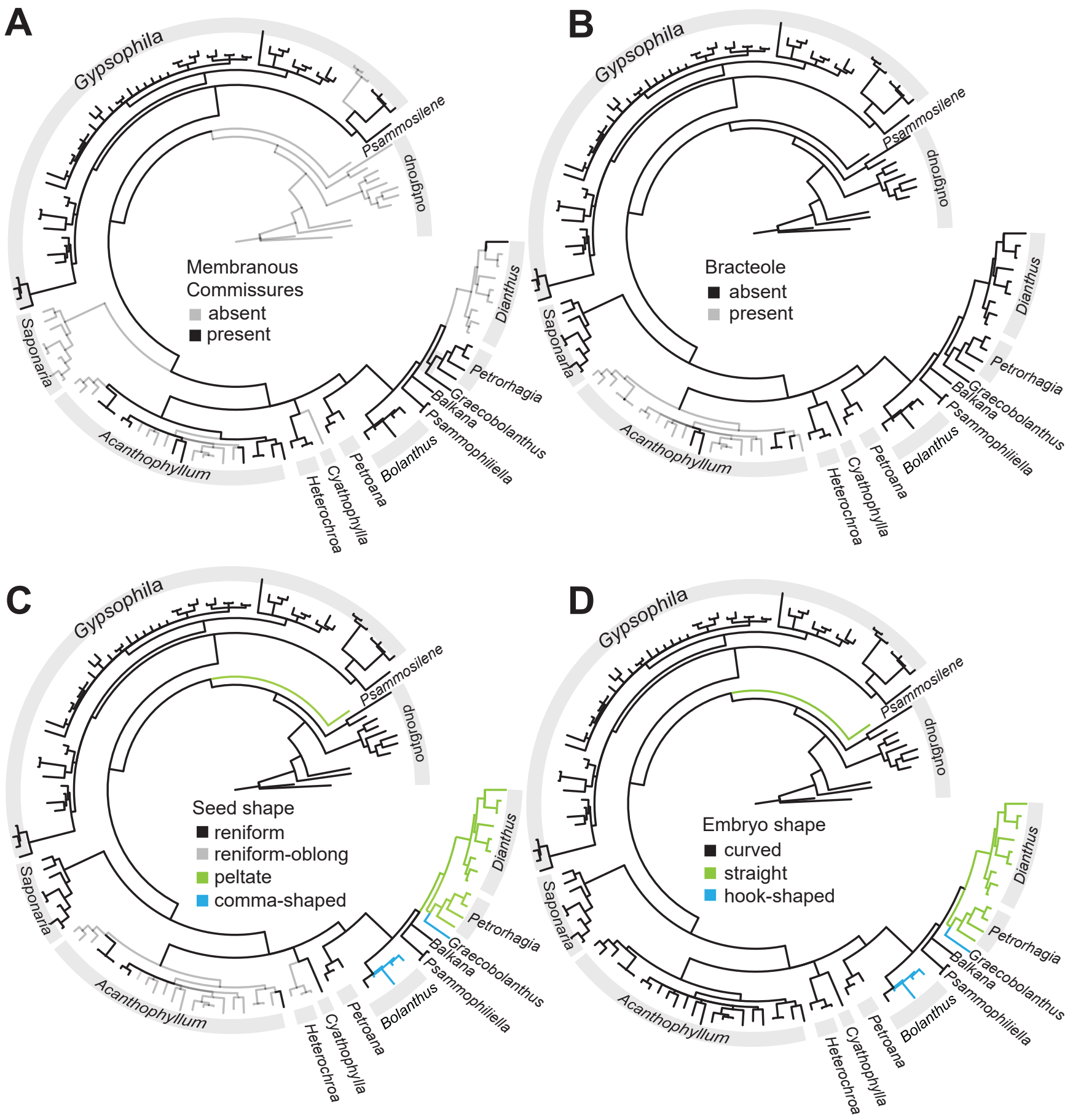

Fig. 5A-D. Evolutionary histories of four selected morphological characters mapped on Bayesian semi-strict consensus tree of nrITS sequences in Caryophylleae. The characters and their states are mentioned in the center of each circular tree. 
axillary inflorescences, sessile flowers, and petals slightly overtopping the calyx are shared by Phrynella ortegioides and several species of Bolanthus. Our results are partly in accordance with Barkoudah's (1962) morphological concept, associating Phrynella with B. minuartioides. However, he transferred the latter to Acanthophyllum mainly due to its rigid habit, linear parallel-nerved leaves, sessile axillary and terminal flowers and unequal stamens (Barkoudah, 1962). The analyses presented here, despite showing a close relationship between Ph. ortegioides and B. minuartioides, rejects their affinity with Acanthophyllum.

Evolution of selected morphological characters. - Mapping of morphological characters on the consensus ITS tree shows that most of the diagnostic traits used formerly in tribe Caryophylleae are homoplasious and not useful for defining the boundaries between the genera (Fig. 5A-D). Therefore, from a taxonomic point of view, it is inevitable that we apply a combination of characters for defining the genera in this group, noting that only a few genera might show no overlap in these characters. It appears as if membranous commissures between the sepals evolved in basal branches of the ITS tree (Fig. 5A), suggesting a reversal of this character in some species or species groups in Acanthophyllum and Dianthus. However, in Psammosilene, which occupies a basal position in Caryophylleae, commissural membranes are absent, and the membranous parts of the calyx are confined to tooth margins. Seed shape (Fig. 5C) in the members of Caryophylleae is quite variable and, therefore, we determined four states for this character. Peltate, dorsiventrally compressed seeds, which have been considered as a major synapomorphy for Dianthus, are shared by Petrorhagia, Psammosilene and Velezia, among which Psammosilene is not closely related to Dianthus. Within the Dianthus s.l. clade the peltate shape is the most common state, but the reniform type (as in Gypsophila spergulifolia $=$ Balkana spergulifolia (Griseb.) Madhani \& Zarre: see below under Taxonomic implications) and the comma-shaped type (as in Bolanthus spp.) represent some cases of homoplasy regarding this character state. Ball \& Heywood (1964) considered the peltate seeds as a feature separating the genera Dianthus, Petrorhagia and Velezia from all other members of Silenoideae, but recent studies reported this seed type also in Psammosilene (Bittrich, 1993). In Acanthophyllum s.l. and Heterochroa, the common seed shape is the reniform-oblong, which can be considered as intermediate between reniform and peltate types. A detailed seed micromorphological investigation in the Dianthus s.l. clade, like those already conducted on Gypsophila (Amini \& al., 2011), Velezia (Poyraz \& Ataşlar, 2010) and Acanthophyllum (Pirani \& al., in prep.), will shed light on the evolutionary pathways of this character.

The curved embryo is the most common type in the basally branching clades of Caryophylleae except Psammosilene, which has a straight embryo, but the straight and hook-shaped ones are most common in members of the Dianthus s.l. clade suggesting a derived position for this state (Fig. 5D). Embryo shape is otherwise correlated with seed shape, so that reniform/reniformoblong, peltate, and comma-shaped seeds show curved, straight, and hook-shaped embryos, respectively.
Another important morphological character addressed in the present study is the presence/absences of bracteoles (Fig. 5B). Presence of bracteoles in Allochrusa, Diaphanoptera, Ochotonophila and Scleranthopsis, reflects their phylogenetic position nested within Acanthophyllum. However, absence of bracteoles in other taxa of Acanthophyllum s.l. clade (Gypsophila cerastioides, G. hernarioides, G. honigbergeri, G. myriantha), suggests at least two reversals for this character in this clade.

\section{- TAXONOMIC IMPLICATIONS}

The molecular phylogenetic analyses performed here, together with morphological and geographic evidence, suggest a new generic concept in tribe Caryophylleae. It is necessary to transfer some species to other genera or describe new genera in order to make them natural and monophyletic. Based on this new concept, we provide a diagnostic key to all genera we currently recognize in the tribe and then brief descriptions of each genus (most based on Bittrich, 1993 and modified as necessary). New combinations are made only when material of the taxa was available to us for analysis. Therefore, for many taxa we did not propose any taxonomic change due to lack of specimens for detailed herbarium or molecular examination.

Diagnostic key to genera of Caryophylleae. - In many genera there are a few species showing some deviation from the typical variation exhibited within the genus. In most cases, it is necessary to use a combination of characters in order to determine the genus with certainty.

1. Seeds peltate, with central (facial) hilum; embryo straight ...................................... 2

1. Seeds reniform, reniform-oblong or comma-shaped, with lateral hilum; embryo curved or hook-shaped ....... 5

2. Leaves with short petiole, ovate; stamens 5; capsules membranous, nearly indehiscent ....... Psammosilene

2. Leaves sessile, linear, subulate, grass-like; stamens (5)10; capsules papery, dehiscent ....................... 3

3. Calyx without membranous commissures, with 35 or more veins, rarely 5- to 15 -nerved (cf. Velezia); calyx tube long tubular, teeth straight...... Dianthus (incl. Velezia)

3. Calyx with membranous commissures, with 5-15 veins; calyx tube variously shaped, if tubular the teeth recurved to deflexed ........................................... 4

4. Seeds $>1.5 \mathrm{~mm}$, with thin margin, smooth on surface .................... Dianthus (incl. Petrorhagia p.p.)

4. Seeds $<1.5 \mathrm{~mm}$, with thickened margin, reticulate on surface ................................... Petrorhagia

5. Seeds comma-shaped (or oblong), with hook-shaped embryo ........................................... 6

5. Seeds reniform to reniform-oblong, embryo curved .. 7

6. Petals turning abruptly downward and becoming clearly deflexed (Greece) ..................... Graecobolanthus

6. Petals recurved gradually (Turkey to the coastal mountains of Syria, Lebanon and Palestine)

Bolanthus (incl. Phrynella) 
7. Calyx bladdery inflated, or turbinate, constricted at teeth, commissural regions membranous hyaline, sometimes wing-like

Diaphanoptera

7. Calyx campanulate to tubular, if inflated, commissural regions papery or leafy and main veins with leafy

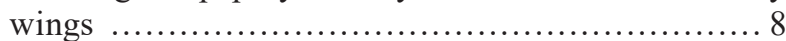

8. Bracteoles present, leafy, papery or rarely membranous; calyx papery in texture or only membranous at intervals ..................................Acanthophyllum (incl. Allochrusa, Ochotonophila, Scleranthopsis)

8. Bracteoles absent .................................. 9

9. Calyx bladdery inflated, nerves prominent and thick, costate, or winged, midveins 5; bracteoles membranous hyaline .................... Gypsophila (cf. Vaccaria)

9. Calyx tubular, campanulate, or obconical, not much inflated, lateral nerves obscure, not prominent and thick, midveins 5 or more; bracteoles absent ............ 10

10. Calyx obscurely nerved or with $15-25$ nerves, commissures absent or present; petals inconspicuous, or clawed, mostly with appendages.................... .11

10. Calyx 5-nerved, with membranous commissures; petals not or only indistinctly clawed, without appendages.. 12

11. Plants annual; inflorescences congested; capsule slightly longer than the calyx; coronal scales absent

Cyathophylla

11. Plants annual, biennial or perennial; inflorescences usually lax; capsule mostly shorter than the calyx; coronal scales mostly present

Saponaria

12. Leaves fleshy, spathulate; flowers very small: calyx $<4 \mathrm{~mm}$, corolla $<5 \mathrm{~mm}$; seed testa with swollen cells tuberculate on periclinal wall, testa cells polygonal-oblong, moderately elongated (Iberian Peninsula, Socotra) .. Petroana

12. Leaves not fleshy or subfleshy, linear to ovate; flowers small or large; seed testa variously shaped, with or without tubercles

13. Petals bicolored, red on the outer surface, white or pink on the inner surface; leaves triquetrous, mostly 3 or 4 at each node (Albania, Serbia, Bosnia) ......... Balkana

13. Petals always concolored, variously colored; leaves slender, in few species triquetrous, then the plants mostly caespitose, paired at nodes ..................... 14

14. The stigmatic surface terminal; ovules less than $24 \ldots 15$

14. The stigmatic surface extending along the inner side of

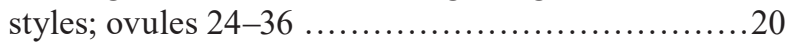

15. Stem nodes with small lateral shoots in leaf axils giving a verticillate appearance; leaves acerose, spiny, or terminating to a spine ............... Acanthophyllum

15. Lateral shoots in leaf axils absent; leaves not spiny except in Gypsophila acantholimoides and G. pinifolia ...... 16

16. Capsules shorter than the calyx .................. 17

16. Capsules exceeding the calyx $\ldots \ldots \ldots \ldots \ldots \ldots \ldots . . . \ldots 18$

17. Plants annual, shorter than $10 \mathrm{~cm}$, covered by long glandular hairs

Bolanthus confertifolius

17. Plants perennial, if annual then taller than $10 \mathrm{~cm}$ and glandular hairs absent or short ............ Gypsophila

18. Plants perennial; capsules \pm indehiscent ............... Acanthophyllum (cf. A. cerastioides)
18. Plants annual or perennial; capsules dehiscent ...... 19

19. Calyx without membranous commissural intervals or with very narrow ones, calcium oxalate crystals absent; stamens shorter than the petals ........... Heterochroa

19. Calyx with membranous commissural intervals encompassing calcium oxalate crystals; stamens longer (or sometimes shorter) than petals .................. 20

20. Annual plants with fibrous roots, puberulent below and glabrous in inflorescence (subcosmopolitan, absent in Australia and New Zealand) ......... Psammophiliella

20. Annual or perennial plants with tap root, variously hairy Gypsophila

\section{Accepted genera and taxonomic changes}

1. Acanthophyllum C.A.Mey., Verz. Pfl. Casp. Meer.: 210. 1831 - Type (designated by Schiman-Czeika in Rechinger, Fl. Iranica 163: 274. 1988): Acanthophyllum mucronatum C.A.Mey.

$=$ Timaeosia Klotzsch in Klotzsch \& Garcke, Bot. Ergebn. Reise Waldemar: 138, t. 33. 1862 - Type: T. cerastioides (D.Don) Klotzsch (三Acanthophyllum cerastioides (D.Don.) Madhani \& Zarre).

= Allochrusa Bunge ex Boiss., F1. Orient. 1: 559. $1867 \equiv$ Acanthophyllum subg. Allochrusa (Bunge) Schischk., F1. URSS 6: 608. 1936 E Acanthophyllum sect. Allochrusa (Bunge ex Boiss.) Pirani \& Rabeler in Phytotaxa 303(2): 198. 2017 - Type (designated by J.J. Swart, ING Card 13030, 1 Apr 1961): Allochrusa versicolor (Fisch. \& C.A.Mey.) Boiss. (三 Acanthophyllum versicolor Fisch. \& C.A.Mey.).

= Ochotonophila Gilli in Feddes Repert. Spec. Nov. Regni Veg. 59: 169. 1956 E Acanthophyllum sect. Ochotonophila (Gilli) Pirani in Taxon 63(3): 604. 2014 - Type: O. allochrusoides Gilli (三 Acanthophyllum alluchrusoides (Gilli) Pirani).

= Kuhitangia Ovcz. in Dokl. Akad. Nauk Tadzhiksk. S.S.R. 10: 50. 1967 - Type: K. popovii (Preobr.) Ovcz. (三 Acanthophyllum popovii (Preobr.) Barkoudah).

$=$ Scleranthopsis Rech.f. in Ann. Naturhist. Mus. Wien 70: 37. 1967 - Type: S. aphanantha (Rech.f.) Rech.f. (三Acanthophyllum aphananthum Rech.f.).

= Kabulianthe (Rech.f.) Ikonn. in Bot. Žhurn. (Moscow \& Leningrad) 89(1): 114. $2004 \equiv$ Gypsophila subg. Kabulianthe Rech.f., Fl. Iranica 163: 244. 1988 - Type: K. honigbergeri (Fenzl) Ikonn. (三Acanthophyllum honigbergeri (Fenzl) Barkoudah).

Diagnosis. - Most of the species are spinose and cushionlike, often bracteate and bracteolate, and oblong- reniform seeds.

Description. - Small shrubby, tufted perennial plants, rarely perennial herbs (e.g., Acanthophyllum cerastioides, see below); leaves subulate, acerose, spiny, spring leaves herbaceous, or rarely thinly herbaceous with mostly spinulose apex; flowers often in fragile, \pm dense, globose heads, or lax panicles (sect. Allochrusa) and rarely solitary; calyx tubular-turbinate, or rarely campanulate to campanulate-tubular, 5- to 15-nerved, 5-toothed, sometimes with narrow membranous commissures; petals 5, white, pink, rose or lilac, limbs entire, rarely bifid; 
stamens 10; styles 2; ovary with 4-12(-20) ovules, on a short gynophore; capsule often with 1-2 seeds and opening in various ways; seeds oblong-reniform, or rarely reniform; embryo curved $(2 n=26,30,60,90$; species: ca. 90-100.

Distribution. - SW and Central Asia, one species in China.

Habitat. - Acanthophyllum grows in subalpine steppes, on gravelly, sandy or stony hills and rocky slopes.

\section{Resurrected names}

Acanthophyllum bungei (Boiss.) Trautv. in Trudy Imp. S.Peterburgsk. Bot. Sada 2: 511. 1873 EAllochrusa bungei Boiss., Fl. Orient. 1: 560. 1867 - Holotype: Iran, East Azerbaijan, inter Marand to Jolfa, 1859, A. Bunge s.n. (G barcode G00150411!; isotypes: K barcode K000725639!, W No. W 1988-0009970!).

Acanthophyllum gypsophiloides Regel, Descr. Pl. Nov. Rar. Fedtsch.: 15. $1882 \equiv$ Allochrusa gypsophiloides (Regel) Schischk. in Trudy Bot. Inst. Akad. Nauk S.S.S.R., Ser. 1, Fl. Sist. Vyssh. Rast. 4: 306. 1937 - Type: [Central Asia, Kazakhstan], Kara-Tau, A. Fedtschenko s.n. (LE).

Acanthophyllum honigbergeri (Fenzl) Barkoudah in Wentia 9: 182.1962 三 Silene honigbergeri Fenzl in Endlicher \& Fenzl, Sert. Cabul.: 3. 1836 三 Gypsophila honigbergeri (Fenzl) Boiss., Fl. Orient. 1: 558. $1867 \equiv$ Kabulianthe honigbergeri (Fenzl) Ikonn. in Bot. Zhurn. (Moscow \& Leningrad) 89(1): 114. 2004 - Holotype: [Afghanistan] E montibus prope Kabul, J.M. Honigberger s.n. (W No. W 0048192!; possible isotypes: W No. W 0048249 [not imaged], W No. W 1914-0006602 [not imaged]).

= Gypsophila galiifolia Gilli in Feddes Repert. Spec. Nov. Regni Veg. 59: 165. 1956 - Lectotype (designated by Rechinger, Fl. Iranica 163: 245. 1988): [Afghanistan] near Kabul, $A$. Gilli 1264 (W No. W 1969-0001338!).

Acanthophyllum paniculatum Regel \& Herder in Bull. Soc. Imp. Naturalistes Moscou 39(1): 539. 1866 三 Allochrusa paniculata (Regel \& Herder) Ovcz. \& Czukav. in Ovczinnikov, Fl. Tadzhiksk. S.S.R. 3: 611. 1968 - Holotype: Central Asia, [Kazakhstan, Dzhungarian Alatau] die Hügel in der Nähe des Piquet Sary-bulka am Füsse des Alatau der sieben Flüsse, 2500 ft., ?.1857, C.L. Semenov s.n. (LE).

Acanthophyllum tadshikistanicum (Schischk.) Schischk., F1. URSS 6: 801. 1936 三 Allochrusa tadshikistanica Schischk. in Trudy Bot. Muz. 24: 40. 1932 - Type: Tadjikistan, (Buchara olim), in itinere Kizil-su et Sarai, in declivitatibus montanis ad ripam dextram flum. Kizil-su, D. Divnogorskaja s.n. (LE).

Acanthophyllum transhyrcanum Preobr. in Bot. Mater. Gerb. Glavn. Bot. Sada R.S.F.S.R. 1(3): 1. $1920 \equiv$ Allochrusa transhyrcana (Preobr.) Czerep., Sosud. Rast. S.S.S.R.: 154. $1981 \equiv$ Diaphanoptera transhyrcana (Preobr.) Rech.f. \& Schiman-Czeika in Rechinger, Fl. Iranica 163: 335. 1988
- Holotype: Turkmenistan: Mulla-Kara, in deserto prope Balchan, 1889, A. Antonow s.n. (LE; isotype: W No. W 1986-0005948!).

Acanthophyllum versicolor Fisch. \& C.A.Mey. in Index Seminum (St. Petersburg [Petropolitanus]) 4: 31. 1838 $\equiv$ Allochrusa versicolor (Fisch. \& C.A.Mey.) Boiss., F1. Orient. 1: 559. 1867 - Holotype: [Azerbaidzhan, Armenia], in locis lapidosis aridissimis desertisque salsis provinciae Nakitschiwan, J.N. Szovits s.n. (LE; possible isotype: US barcode 00289322!).

New combinations

Acanthophyllum cerastioides (D.Don) Madhani \& Zarre, comb. nov. $\equiv$ Gypsophila cerastioides D.Don, Prodr. F1. Nepal.: 213. $1825 \equiv$ Timaeosia cerastioides (D.Don) Klotzsch in Klotzsch \& Garcke, Bot. Ergebn. Reise Waldemar: 138. 1862 - Holotype: [Nepal], Gosaingsthan, 1980-3900 m, 1829, M. Wallich Cat. 644 (K barcode K000725774!; isotypes: E barcode E00301689, G barcode G00226904!).

Acanthophyllum herniarioides (Boiss.) Madhani \& Zarre, comb. nov. $\equiv$ Gypsophila herniarioides Boiss., Fl. Orient., Suppl.: 84. 1888 - Holotype: Afghanistan, Kurrum valley, Sikaram, 7 Aug 1879, J.E. Aitchison 961 (G; isotype: K barcode K000725698!).

Acanthophyllum myrianthum (Rech.f.) Madhani \& A.Pirani, comb. nov. $\equiv$ Gypsophila myriantha Rech.f. in Anz. Österr. Akad. Wiss., Math.-Naturwiss. K1. 105: 11. 1969 - Holotype: Afghanistan, Deh Kundi, in declivibus saxosis aridis (Tonschiefer) $10 \mathrm{~km} \mathrm{~W}$ Shahrestan, $33^{\circ} 40^{\prime} \mathrm{N}$, $66^{\circ} 35^{\prime} \mathrm{E}$, versus Deh Kundi, 34 $4^{\circ} 10^{\prime} \mathrm{N}, 66^{\circ} 07^{\prime} \mathrm{E}, 2200 \mathrm{~m}$, 2 Jul 1967, K.H. Rechinger 36812 (W No. W 1969-0013845!; isotypes; B barcode B 10 0365629!, E barcode E00301855!, G barcode G00226867!, K barcode K000725739!, LE barcode LE 00012091!, MO barcode MO-176943!, S No. S-G8666 !, US barcode 00103460 !).

Acanthophyllum persicum (Boiss.) A.Pirani \& Rabeler, comb. nov. S Saponaria persica Boiss., Diagn. Pl. Orient., ser. 1, 1: 18. $1843 \equiv$ Allochrusa persica (Boiss.) Boiss., Fl. Orient. 1: 560.1867 - Lectotype (designated here) [following annotation on herbarium sheet by Schiman-Czeika, 1982]: [Iran] in lapidosis circa Tabriz, P.M.R. Aucher-Eloy 4242 (G [herb. Boissier] barcode G00226480!; isolectotypes: G barcode G00226470!, K barcode K000725640!).

Acanthophyllum sedifolium (Kurz) Madhani \& Zarre, comb. nov. $\equiv$ Gypsophila sedifolia Kurz in Flora 55: 285. 1872 Holotype: [India] Kashmir; Zanskar, 12-13,000 ft., 2 Jul 1848, T. Thomson s.n. (B, destroyed) - Lectotype (designated here): (K barcode K000725777!).

Acanthophyllum takhtajanii (Gabrieljan \& Dittrich) A.Pirani \& Rabeler, comb.nov. $\equiv$ Allochrusa takhtajanii Gabrieljan \& 
Dittrich in Biol. Žhurn. Armenii 43: 184. 1990 - Holotype: Armenia, Ararat Distr., lower part of Uztz mountains near Surenavan, 800 m, 20 Jun 1986, E.T. Gabrieljan \& K.G. Tamanian s.n. (ERE barcode ERE0000046!; isotype: G barcode G00226486!).

2. Balkana Madhani \& Zarre, gen. nov. - Type: Balkana spergulifolia (Griseb.) Madhani \& Zarre.

Diagnosis. - This monotypic genus differs from all other genera of Caryophylleae by its verticillate phyllotaxy at least at some nodes, as well as leaves distinctly swollen and connate at base.

Description. - Perennial herbs; leaves linear, triquetrous, (2-)3-4 at each node; flowers in terminal panicles composed of dichasial partial inflorescences; pedicel longer than the calyx; calyx campanulate-turbinate with 5 veins and membranous commissures; petals 5 , bicolored, outer surface red, inner surface white or pink; stamens 10; styles 2; ovules ca. 16; capsule opening by 4 teeth; seeds reniform with small flat tubercles; embryo curved; monotypic.

Etymology. - Balkana is named after the general distribution of the plants which is centered in Balkan Peninsula.

Distribution. - The genus is a Mediterranean element distributed in the inner and western part of the Balkan Peninsula: Albania, Serbia, Bosnia-Herzegovina.

Habitat. - These plants are thermophilous, growing on limestone or serpentine soils.

\section{Included species}

Balkana spergulifolia (Griseb.) Madhani \& Zarre, comb. nov. $\equiv$ Gypsophila spergulifolia Griseb., Spic. Fl. Rumel. 1: 183. 1843, non G. spergulifolia (Jaub. \& Spach) Boiss., Fl. Orient. 1: 559.1867 - Holotype: W Albania, Mt. Puka near Alessia, A.H.R. Griesbach s.n. (GOET barcode GOET005978!; isotype: $\mathrm{K}$; possible isotype: $\mathrm{M}$ barcode M-0242533!).

3. Bolanthus (Ser.) Rchb., Deut. Bot. Herb.-Buch: 205. $1841 \equiv$ Saponaria sect. Bolanthus Ser. in Candolle, Prodr. 1: 366. $1824 \equiv$ Gypsophila sect. Bolanthus (Ser.) Boiss., Fl. Orient. 1: 537. 1867 - Type (designated by Barkoudah in Wentia 9: 168. 1962): B. hirsutus (Labill.) Barkoudah.

$=$ Phrynella Pax \& K.Hoffm. in Engler \& Prantl, Nat. Pflanzenfam., ed. 2, 16c: 364.1934 三 Phryna (Boiss.) Pax \& K.Hoffm. in Engler \& Prantl, Nat. Pflanzenfam., ed. 2, 16c: 351. 1934, non Phryna Bubani 1901, syn. nov. - Type: P. ortegioides (Fisch. \& C.A.Mey.) Pax \& K.Hoffm. (三 Bolanthus ortegioides (Fisch. \& C.A.Mey.) Madhani \& Rabeler).

Diagnosis. - Seeds in the members of this genus (except B. confertifolius) are comma-shaped and the embryo is hookshaped. The projecting veins on the tubular calyx give a pentagonal shape to the calyx in these plants. Unlike its related genus Graecobolanthus, the petals in members of Bolanthus are recurved gradually, not abruptly deflexed.

Description. - Perennials, low prostrate or cushion-forming, or rarely annual (B. confertifolius), plants hairy; leaves small and linear; flowers small, in paniclulate to subcapitate dichasia or solitary; calyx tubular-turbinate with 5 projecting veins and membranous commissures; petals 5 , recurved gradually, white or pink with purple veins; stamens 10; styles 2; ovary on a short gynophore; capsule opening by 4 teeth; seeds comma-shaped with prominent radicle; embryo hook-shaped; species ca. 10.

Etymology. - From the Greek bolosi: lump+nugget+ anthos: flower.

Distribution. - The genus includes East Mediterranean elements, reaching higher elevations in western parts of the Mediterranean from Turkey to Syria, Lebanon and Palestine.

Habitat. - These plants mostly grow in crevices of calcareous rock and on stony slopes.

\section{New combinations}

Bolanthus confertifolius (Hub.-Mor.) Madhani \& Heubl, comb. nov. $\equiv$ Gypsophila confertifolia Hub.-Mor. in Feddes Repert. Spec. Nov. Regni Veg. 52: 42. 1943 - Holotype: [Turkey, C2] Muğla: Muğla-Fethiye, 141 km SE of Muğla, 7 Jun 1938, J. Reese s.n. (G barcode G00006010! [ex Hb. Huber-Morath]; isotype: BASBG).

Bolanthus ortegioides (Fisch. \& C.A.Mey.) Madhani \& Rabeler, comb. nov. $\equiv$ Tunica ortegioides Fisch. \& C.A. Mey. in Ann. Sci. Nat., Bot., sér. 4, 1: 36.1854 ("artegioides") $\equiv$ Saponaria ortegioides (Fisch. \& C.A.Mey.) Boiss. \& Balansa in Boissier, Diagn. Pl. Orient., ser. 2, 6: 25. $1859 \equiv$ Gypsophila ortegioides (Fisch. \& C.A.Mey.) Boiss., Fl. Orient. 1: 552. $1867 \equiv$ Phryna ortegioides (Fisch. \& C.A.Mey.) Pax \& K.Hoffm. in Engler \& Prantl, Nat. Pflanzenfam., ed. 2, 16c: $351.1934 \equiv$ Phrynella ortegioides (Fisch. \& C.A.Mey.) Pax \& K.Hoffm. in Engler \& Prantl, Nat. Pflanzenfam., ed. 2, 16c: 364. 1934 - Holotype: [Turkey, B5], Ali Dag, near Kayseri, M. de Tchihatcheff 601 (P barcode P01903203!).

= Tunica xylorrhiza Boiss. in Ann. Sci. Nat., Bot., sér. 4, 2: 246. 1854 - Type: [Turkey, Tokat] In locis montosis sylvaticis Ponti meridionalis inter pagum Almus et urbem Niksar, M. de Tchihatcheff s.n. (G [herb. Boissier]).

Note. - The type specimen of Tunica ortegioides is probably also the type of T. xylorrhiza; further study is required to clarify whether these names are based on same collection/plant.

4. Cyathophylla Bocquet \& Strid in Strid, Mount. Fl. Greece 1: 175. 1986 - Type: C. chlorifolia (Poir.) Bocquet \& Strid (三Cucubalus chlorifolius Poir.).

Diagnosis. - Capsules exceeding the calyx, congested inflorescences in both species of this genus, perfoliate leaves in the type (C. chlorifolia), and dense glandular indumentum covering the entire plant in C. viscosa (C.A.Mey.) Madhani \& Rabeler, are the characteristics separating Cyathophylla from Saponaria.

Description. - Annual herbs, glabrous or with glandular hairs covering entire plant; leaves linear-lanceolate or ovate to rounded, perfoliate or shortly petiolate; flowers in a capitate 
inflorescence; calyx tubular-cylindric or tubular-ovoid, 5-15 veins lacking membranous commissures; petals 5 , rose or pink, linear to linear-oblong; stamens 10; styles 2; capsule oblongovate, opening by 4 teeth; seeds reniform with flat tubercules; embryo hookshaped; 2 species.

Etymology. - From the Greek cyath: a cup + phylla: leaves.

Distribution. - Greece, Turkey, Iraq, Azerbaijan, Iran, and Turkmenistan.

Habitat. - In rocky slopes, mostly on limestone.

\section{New combination}

Cyathophylla viscosa (C.A.Mey.) Madhani \& Rabeler, comb. nov. $\equiv$ Saponaria viscosa C.A.Mey., Verz. Pfl. Casp. Meer.: 212. 1831 - Holotype: [Azerbaijan], Talysh, Swant, C.A. von Meyer 145 (LE; isotype: E).

5. Dianthus L., Sp. Pl.: 409. 1753 - Type (designated by Hitchcock \& Green, in Sprague, Nom. Prop. Brit. Bot.: 155. 1929): D. caryophyllus L.

$=$ Velezia L., Sp. Pl.: 332. 1753 - Type: V. rigida L.

Diagnosis. - Peltate seeds and straight embryos are characteristic features of the members of this genus. An epicalyx is often present and membranous commissures are usually absent (except: Dianthus candicus (P.W.Ball \& Heywood) Madhani \& Heubl, D. recticaulis Ledeb., D. nudiflorus Griff. and D. tunicoides (Ser. ex DC.) Madhani \& Heubl, see below).

Description. - Annual or perennial herbs, rarely subshrubs; leaves grass-like, often linear to oblong (ovate); flowers mostly hermaphrodite or rarely unisexual, solitary or in capitate (rarely paniculate or monochasial) cymes, often subtended by bracts, and calyx mostly subtended by two or many epicalyx scales; calyx tubular with 20-60 parallel veins, without membranous commissures or rarely 5- to 15-veined (former Petrorhagia spp. and Velezia rigida) and sometimes with membranous commissures (former Petrorhagia spp.), 5-toothed; petals white, pink or red, rarely yellow, limb entire, toothed or fimbriate, without coronal scales; stamens 10; styles 2; ovary on a short gynophore; capsule opening by 4 teeth; seeds many, peltate; embryo straight; $2 n=26$ (Dianthus tunicoides), 28, 30, 60, 90; species more than 300 .

Etymology. - Dianthus is the contracted form of Diosanthos; from Greek Dios-: of Zeus + anthos: flower.

Distribution. - Europe, Asia, and Africa, especially in Mediterranean regions; introduced in North and South America, Hawaii, and Australia.

Habitat. - Mostly in hillsides, mountain slopes, dry meadows, and rocky hills.

\section{Resurrected name}

Dianthus nudiflorus Griff., Not. Pl. Asiat. 4: 466. 1854 Holotype: Afghanistan, barren rocky mountains around Otipore, 7 Apr 1839, W. Griffith 132 (K).

$=$ Velezia rigida L., Sp. Pl.: 332. 1753 - Lectotype (designated by Strid in Taxon 53: 1053. 2004): Loefling 307, Herb. Linn. No. 326.1 (LINN).
Note. - Since the name Dianthus rigidus had already been used by Marschall von Bieberstein (Fl. Taur.-Caucas. 1: 325. 1808), this name was not available for a new combination. Therefore, one of the oldest synonyms of this species under Dianthus (i.e., D. nudiflorus Griff. 1854) is resurrected here.

\section{New combinations}

Dianthus candicus (P.W.Ball \& Heywood) Madhani \& Heubl, comb. nov. $\equiv$ Petrorhagia candica P.W.Ball \& Heywood, Bull. Brit. Mus. (Nat. Hist.), Bot. 3: 141. $1964 \equiv$ Fiedleria candica (P.W.Ball \& Heywood) Ovcz., Fl. Tadzhikskoi S.S.R. 3: 608. 1968 - Holotype: [Greece], Crete, Sitia, May 1846, T.H.H. Heldreich s.n. (BM; isotypes: CGE, K barcodes K000725564! \& K000725566!).

Dianthus strictiformis Madhani \& Zarre, nom. nov., non Dianthus strictus Banks ex Sol. in Russel, Nat. Hist. Aleppo, ed. 2, 2: 252. 1794 Eypsophila stricta Bunge in Ledeb., Fl. Altaic. 2: 129. 1830 三 Tunica stricta (Bunge) Fisch. \& C.A.Mey. in Index Seminum (St.Petersburg [Petropolitanus] ) 4: 50. 1837 DDianthus recticaulis Ledeb., Fl. Ross. 1(2): 287. 1842, nom. superfl. [citing G. stricta and Tunica stricta in synonymy] - Holotype: Russia, in siccis prope Buchtorminsk et Alexandrowsk, in rupestribus prope pagum Krasnojarsk ad fl. Irtysch, C.F. Ledebour s.n. (LE).

$=$ Petrorhagia alpina (Hablitz) P.W.Ball \& Heywood in Bull. Brit. Mus. (Nat. Hist.), Bot. 3: 145. $1964 \equiv$ Gypsophila alpina Hablitz in Neueste Nord. Beytr. Phys. Geogr. ErdVölkerbeschreib. 4: 57. $1783 \equiv$ Tunica alpina (Hablitz) Bobrov in Bot. Zhourn. S.S.S.R. 43: 1546. $1958 \equiv$ Fiedleria alpina (Hablitz) Ovcz. in Dokl. Akad. Nauk Tadzhiksk. S.S.R. 7: 52. 1967 - Holotype: [Russia] Siberia, Irtysh River, gravelly banks, 2000-3000 m, C.L. von Hablitz s.n. (LE).

Dianthus tunicoides Madhani \& Heubl, nom. nov., non D. armerioides Raf. in J. Bot. (Paris) 4: 269. $1814 \equiv$ Gypsophila armerioides Ser. ex DC., Prodr. 1: 353. 1824 $\equiv$ Tunica sibthorpii Boiss. in Diagn. Pl. Orient., ser. 1, 8: 61. 1849, nom. illeg., = Tunica armerioides (Ser. ex DC.) Halácsy, Consp. Fl. Graec. 1: 194. $1900 \equiv$ Petrorhagia armerioides (Ser. ex DC.) P.W.Ball \& Heywood in Bull. Brit. Mus. (Nat. Hist.), Bot. 3: 139. 1964 三Fiedleria armerioides (Ser. ex DC.) Ovcz., Fl. Tadzhikskoi S.S.R. 3: 608. 1968 - Holotype: Turquie [Turkey], Troade, G.A. Olivier s.n. (G-DC barcode G00214254!; isotype: MW).

6. Diaphanoptera Rech.f. in Repert. Spec. Nov. Regni Veg. 48: 41. 1940 - Type: D. khorasanica Rech.f.

Diagnosis. - The members of this genus are characterized by their membranous winged-vein calyces.

Description. - Perennial tufted plants, woody at base and sometimes glandular pubescent; leaves slightly succulent; flowers in lax few-flowered cymes; bracts and bracteoles often present; calyx turbinate, membranous, with 5 prominent or winged veins, 5-toothed; petals 5, rose or violet, entire or emarginate; stamens 10 ; styles 2 ; ovary obovate, on a gynophore, ovules 
(6-)8-19; capsule opening by 4 teeth; seeds reniform; embryo curved; species 6.

Etymology. - From Ancient Greek diaphanếs: transparent + ptron: wing.

Distribution. - Mountainous areas up to $3800 \mathrm{~m}$ in NE Iran, Turkmenistan, and Afghanistan.

Habitat. - High altitudes of mountain peaks, on serpentine, calcareous or rocky substrates.

7. Graecobolanthus Madhani \& Rabeler, gen. nov. - Type: G. graecus (Schreb.) Madhani \& Rabeler (三 Saponaria graeca Schreb.).

Diagnosis. - This new genus differs from Bolanthus mainly by its abruptly deflexed petals.

Description. - Perennial herbs; caudex woody and thick, leaves paired at nodes, small, linear, linear-lanceolate, lanceolate or spathulate; flowers in lax dichasial or capitate inflorescences; calyx tubular-turbinate with 5 winged veins and membranous commissures; petals 5 , abruptly deflexed, white or purple; stamens 10 ; styles 2 , stigmatic surface all along the inner side; ovary on a short gynophore; ovules 8-28; capsule opening by 4 teeth; seeds comma-shaped with small tubercles on testa and with a prominent radicle; embryo hook-shaped; $2 n=20$; species 8 .

Etymology. - From Latin Graeco: Greek+Bolanthus.

Distribution. - The members of this genus are Mediterranean elements restricted to Greece, in particular to Peloponnese Peninsula.

Habitat. - The members of this genus are found in mountainous areas and mainly inhabit rocky and stony slopes.

\section{Included species}

Graecobolanthus chelmicus (Phitos) Rabeler \& Madhani, comb. nov. $\equiv$ Bolanthus chelmicus Phitos in Bot. Chron. (Patras) 1(1): 40. 1981 - Holotype: Greece, prov. Achaia: mons Chelmos, supra pagum Peristera, in declivibus orientalibus, 1100-1200 m, Georgiadis 1783 (UPA).

Graecobolanthus creutzburgii (Greuter) Rabeler \& Madhani, comb. nov. $\equiv$ Bolanthus creutzburgii Greuter in Candollea 20: 210. 1965 - Holotype: Greece, Creta, prov. Pirjotísi, NW-Hang des Berges Mavri, ob. der Quelle Skaronero, Tripolitaa-Kalk, 1800-1900m, 30 Jun 1961, W. Greuter 3733 (PAL [herb. Greuter]; isotypes: G barcode G00226560!, W No. W 1966-0016564!, Z).

Graecobolanthus fruticulosus (Bory \& Chaub.) Madhani \& Zarre, comb. nov. $\equiv$ Saponaria fruticulosa Bory \& Chaub. in Bory \& al., Exp. Sci. Morée, Bot.: 118. $1832 \equiv$ Gypsophila fruticulosa (Bory \& Chaub.) Boiss., Fl. Orient. 1: $556.1867 \equiv$ Bolanthus fruticulosus (Bory \& Chaub.) Barkoudah in Wentia 9: 164. 1962 - Holotype: [Greece, Peloponnese] Coteaux de Laconie, 1829, J.B.G.M. Bory s.n. (P barcode P04982600!).

Note. - Phitos (1981) designated a lectotype (P04982599) that he notes was collected in 1833 . Since this specimen was collected after the species protologue, this lectotypification cannot be considered as effective (McNeill \& al., 2012: Art. 9.3).

Graecobolanthus graecus (Schreb.) Madhani \& Rabeler, comb. nov. $\equiv$ Saponaria graeca Schreb. in Nova Acta Phys.-Med. Acad. Caes. Leop.-Carol. Nat. Cur. 4: 138. $1770 \equiv$ Gypsophila graeca Britten in J. Bot. 44: 345. 1906 $\equiv$ Bolanthus graecus (Schreb.) Barkoudah in Wentia 9: 164. 1962 - Lectotype (designated by Phitos in Strid \& Tan, Fl. Hellenica 1: 327. 1997): "Lychnis pumila, umbellifera, Polygoni folio, flore albo, cum circulo atro-purpureo", Tournefort 3032 (P-TRF).

$=$ Cucubalus polygonoides Willd., Sp. Pl. 2: 690. $1799 \equiv$ Silene polygonoides (Willd.) Pers., Syn. Pl. 1: 500. 1805 $\equiv$ Saponaria polygonoides (Willd.) Jaub. \& Spach, Ill. Pl. Orient. 5: 2, t. $402.1853 \equiv$ Gypsophila polygonoides (Willd.) Halácsy in Denkschr. Akad. Wiss. Wien, Math.-Naturwiss. K1. 61: 473. 1894 - Holotype: Greece, Náxos, [Gundelsheimer ex] W. Wierweg 1 (B-W barcode B-W $08601-01$ 0!).

= Gypsophila ocellata Sm. in Sibthorp \& Smith, Fl. Graec. Prodr. 1: 281. $1809 \equiv$ Gypsophila hirsuta var. ocellata $(\mathrm{Sm}$.) Boiss., Fl. Orient. 1: 556. 1867 Eypsophila polygonoides subsp. ocellata (Sm.) Hayek in Repert. Spec. Nov. Regni Veg. Beih. 30(1): 220. 1924 - Lectotype (designated by Phitos in Strid \& Tan, Fl. Hellenica 1: 327. 1997): [Greece, Evonia] in Delphi monte Euboeae, Sibthorp s.n. (OXF [IDC photo 43: A4]).

Graecobolanthus intermedius (Phitos) Rabeler \& Madhani, comb. nov. $\equiv$ Bolanthus intermedius Phitos in Bot. Chron. (Patras) 1(1): 39. 1981 - Holotype: Greece, Ins. Euboea, in saxosis serpentinicis et magesiticis litorcis ad pagu Mantudi [rocky shore, Mantudi], Georgiadis 1657 (UPA).

Graecobolanthus laconicus (Boiss. \& Heldr. ex Boiss.) Madhani \& Zarre, comb. nov. $\equiv$ Gypsophila fasciculata var. laconica Boiss. \& Heldr. ex Boiss., Fl. Orient. 1: 556. $1867 \equiv$ Gypsophila laconica Boiss. \& Heldr. ex Boiss., Fl. Orient., Suppl.: 88. $1888 \equiv$ Bolanthus laconicus (Boiss. \& Heldr. ex Boiss.) Barkoudah in Wentia 9: 163. 1962 Lectotype (designated by Phitos in Bot. Chron. (Patras) 1: 36. 1981): Greece, Peloponnesus, in regione media montis Malevo (Napvov) prope Vromopigadon, $2000 \mathrm{ft}, 7-19 \mathrm{Jul}$ 1850, G.H. Orphanides, Fl. Graeca Exs. 1 (ATHU; isolectotypes: BR barcode 000006970062!, FI, G [herb. Boissier], JE barcodes JE00015406! \& JE00015407!, K barcodes K000725783! \& K000725784!, L, LD barcode 1006486!, US barcode 00589410!, WU No. 0073639!).

Graecobolanthus thessalus (Jaub. \& Spach) Madhani \& Zarre, comb. nov. $\equiv$ Saponaria thessala Jaub. \& Spach, Ill. Pl. Orient. 5: 2. $1853 \equiv$ Gypsophila thessala (Jaub. \& Spach) Halácsy in Consp. Fl. Graec. 1: 191. $1900 \equiv$ Gypsophila polygonoides subsp. thessala (Jaub. \& Spach) Hayek in Repert. Spec. Nov. Regni Veg. Beih. 30(1): 221. $1924-$ Holotype: Greece, Thessaliae, prope Vólos, 1837, P.M.R. 
Aucher-Eloy 566 (P barcode P05075275!, isotypes: BM barcodes BM000572757! \& BM000810718!, FI, K barcodes K000725780! \& K000725781!, P).

Graecobolanthus thymifolius (Sm.) Rabeler \& Madhani, comb. nov. $\equiv$ Gypsophila thymifolia Sm. in Sibthorp \& Smith, Fl. Graec. Prodr. 1: 282. $1809 \equiv$ Saponaria thymifolia Boiss., Diagn. Pl. Orient, ser. 1, 1: 17. 1843 E Gypsophila hirsuta var. thymifolia Boiss., F1. Orient. 1: 556. $1867 \equiv$ Bolanthus thymifolius (Sm.) Phitos in Bot. Chron. (Patras) 1: 39.1981 - Lectotype (designated by Phitos in Strid \& Tan, F1. Hellenica 1: 328. 1997): [Greece, Sterea Ellas] in monte Parnasso, Sibthorp s.n. (OXF [IDC photo 43: A5]).

8. Gypsophila L., Sp. Pl.: 406. 1753 - Type (designated by Hitchcock \& Green in Sprague, Nom. Prop. Brit. Bot. 154. 1929): G. repens L.

= Rokejeka Forssk., Fl. Aegypt.-Arab.: 90. 1775 - Type: R. capillaris Forssk. (三 Gypsophila capillaris (Forssk.) C.Chr.).

= Vaccaria Wolf, Gen. Pl.: III. 1776. - Lectotype (designated by Phillips, Gen. S. African Fl. Pl., ed. 2: 330. 1951): V. pyramidata Medik. (三 Gypsophila hispanica Mill.).

= Hagenia Moench, Methodus: 61. 1794, non J.F.Gmel. 1791 Type: H. filiformis Moench (= Gypsophila pilosa Huds.).

= Arrostia Raf., Caratt. Nouv. Gen.: 75. 1810 - Type: A. dichotoma Raf. (三 Gypsophila arrostii (Raf.) Guss.).

= Dichoglottis Fisch. \& C.A.Mey. in Index Seminum (St. Petersburg [Petropolitanus]) 1: 25. 1835 - Type: D. linearifolia Fisch. \& C.A.Mey. (三 Gypsophila linearifolia (Fisch. \& C.A.Mey.) Boiss.).

=Ankyropetalum Fenzl in Bot. Zeitung (Berlin) 1: 393. 1843 - Type: A. gypsophiloides Fenzl (三 Gypsophila gypsophiloides (Fenzl) Blakelock).

= Bolbosaponaria Bondarenko in Kovalevskaja, Opred. Rast. Sred. Azii 2: 327. 1971 - Type: B. sewerzowii (Regel \& Schmalh.) Bondarenko ("severtzowii") (三 Saponaria sewerzowii Regel \& Schmalh ("sewerzowi").

= Pseudosaponaria (F.N.Williams) Ikonn. in Novosti Sist. Vyssh. Rast. 15: 144. 1979 - Type: P. pilosa (Huds.) Ikonn. (三 Gypsophila pilosa Huds.).

Diagnosis. - The members of this genus are separated from Acanthophyllum, Heterochroa and Saponaria by the presence of distinct membranous commissures and calcium oxalate druses in the mesophyll of the calyx. They differ from Acanthophyllum, Bolanthus and Petrorhagia by reniform or reniform-globular seeds. The concolored petals and opposite phyllotaxy can discriminate these species from Balkana (see above).

Description. - Annual or perennial herbs to tufted caespitose or pulvinate subshrubs; leaves linear or even spiny to lanceolate and ovate, often somewhat fleshy; flowers hermaphrodite or sometimes unisexual, in many-flowered lax thyrses or panicles, or compact head-like or few-(uni-)flowered racemelike monochasia; bracts present; pedicel longer than the calyx; calyx campanulate-turbinate or tubular, mostly with calcium oxalate druses, with 5 veins and membranous commissures, or inflated with 5 winged veins and lacking membranous commissures; petals 5, white, pink, or purple, often concolorous (upper and lower side) with purple veins; stamens 10, rarely 5; styles 2(-3), stigmatic surface extending all along the style; ovules 4-36; capsule opening by 4 valves; seeds reniform; embryo curved; $2 n=12,24,26,28,30,34,36,48,51,60,68$; species ca. 150 . loving.

Etymology. - From Greek gypsos: chalk, gypsum + philos:

Distribution. - Temperate regions of Eurasia, Africa, Pacific Islands, with one species extending to Australia; introduced in North and South America.

Habitat. - Mostly in steppes on calcareous hills, dry or rocky slopes, and sandy soils, sometimes weeds on farms, some species ruderals growing along roadsides.

\section{Resurrected names}

Gypsophila arsusiana (Kotschy ex Boiss.) F.N.Williams in J. Bot. 27: 322. 1889 EAnkyropetalum arsusianum Kotschy ex Boiss., Fl. Orient. 1: 533. 1867 - Syntypes: [Turkey C5 Hatay], Mount Amanus, supra Arsus, 2 Jul 1862, Th. Kotschy 117 (G [herb. Boissier]; isosyntypes: JE barcodes JE00015413! \& JE00015412!, K barcode K000725802!, L barcode L 0038665!, P barcodes P01903163!, P01903164! \& P01903165!); Mount Akkerdagh prope Marasch, Haussknecht s.n. (G [herb. Boissier], JE).

Gypsophila bucharica B.Fedtsch. in Trudy Imp. S.-Peterburgsk. Bot. Sada 32: 7. 1911 三 Saponaria bucharica (B.Fedtsch.) Preobr. ex Popov in Trudy Turkestansk. Gosud. Univ. 4: 241922 三Bolbosaponaria bucharica (B.Fedtsch.) Bondarenko in Opred. Rast. Sred. Azii 2: 292. 1971 - Holotype: [Tajikistan], Viloyati Khatlon (Qurghonteppa), Chanatus Buchara, Prov. Baldschuan, in montibus ad pagum Tutkaul in valle fluvii Wachsch, 8 May 1906, G.G. Morren s.n, Anonymous, Ed. Horti Bot. Imp. 10 (LE; isotype: FR barcode FR-0030878!).

Gypsophila gypsophiloides (Fenzl) Blakelock in Kew Bull. 12(2): 193. 1957 E Ankyropetalum gypsophiloides Fenzl in Bot. Zeitung (Berlin) 1: 393. 1843 - Syntypes: [Turkey C8 Mardin], zwischen Mardin, Assuauer und Tichalaga, Th. Kotschy 356 (W, destroyed; isosyntypes: E barcode E00301841!, K barcodes K000725796! \& K000725797!); [Iraq, Kurdistan:] prope Gara, Jul 1841, Th. Kotschy, Pl. Alepp. Kurd. Moss. 406 (W, destroyed; isosyntypes: BM barcode BM000572761!, K barcode K000725795!, HAL barcode HAL0117954!, P barcodes P04982620!, P04982621!, P04982623! \& P04982624!).

Gypsophila reuteri (Boiss. \& Hausskn.) F.N.Williams in J. Bot. 27: $322.1889 \equiv$ Ankyropetalum reuteri Boiss. \& Hausskn. in Boissier, Fl. Orient. 1: 533. 1867 - Holotype: [Turkey], Maras, Akkerdagh, 15 Jul 1861, H.C. Haussknecht s.n. (G [herb. Boissier]; isotype: JE barcode JE00015414!).

Gypsophila vaccaria (L.) Sm. in Sibthorp \& Smith, Fl. Graec. Prodr. 1: 279. 1809 三 Saponaria vaccaria L., Sp. Pl.: 409. 
$1753 \equiv$ Lychnis vaccaria (L.) Scop., Fl. Carniol., ed. 2, 1: 303. $1771 \equiv$ Vaccaria vulgaris Host, Fl. Austriac. 1: 518. $1827 \equiv$ Silene vaccaria (L.) E.H.L.Krause, Deutschl. Fl., ed. 2, 5: 120. 1901 - Lectotype (designated by Sell, 1980, on the sheet): Cultivated material from the garden of George Clifford III: Hartekamp Garden, Holland, Hort. Cliff. 166 (BM barcode BM000628472!).

= Saponaria hispanica Mill., Gard. Dict., ed. 8, in Errata. 1768 $\equiv$ Vaccaria hispanica (Mill.) Rauschert in Wiss. Z. MartinLuther-Univ. Halle-Wittenberg, Math.-Naturwiss. Reihe 14: 496. 1965 - Type: not specified (indicated as “... grows naturally in Spain").

= Saponaria segetalis Neck., Delic. Gallo-Belg. 1: 194. $1768 \equiv$ Vaccaria segetalis (Neck.) Garcke ex Asch., Fl. Brandenburg 1: 84. 1860, nom. illeg. (cited $S$. vaccaria L. in synonymy).

= Saponaria rubra Lam., Fl. Franç. 2: 541. 1779, nom. illeg. (cited $S$. vaccaria L. in synonymy).

= Vaccaria pyramidata Medik. in Philos. Bot. 1: 96. 1789 Syntypes(?): East India, W. Roxburgh S.n. (K barcodes K000725844! \& K000725845!).

= Vaccaria parviflora Moench, Methodus: 63. 1794, nom. illeg. (cited Saponaria vaccaria L. in synonymy).

= Saponaria perfoliata Roxb. ex Willd., Enum. Hort. Berol.: 464. 1809 E Vaccaria perfoliata (Roxb. ex Willd.) Sweet, Hort. Brit., ed. 2: 51. 1830 - Holotype(?): India?, W. Roxburgh s.n. (B barcode B-W 08501 -01 0!; isotype: BR barcode 00006981341!).

= Saponaria vaccaria var. grandiflora Fisch. ex DC., Prodr. 1: 365. 1824 E Vaccaria grandiflora (Fisch. \& DC.) Jaub. \& Spach, Ill. Pl. Orient. 3: 40, t. 231. 1847 E Vaccaria perfoliata var. grandiflora (Fisch. ex Seringe) Halacsy, Consp. Fl. Graec. 1: 190. 1900 = Vaccaria hispanica subsp. grandiflora (Fisch. ex DC.) Holub in Folia Geobot. Phytotax. 11: 83.1976 = Vaccaria hispanica var. grandiflora (Fisch. ex DC.) J.Léonard in Bull. Jard. Bot. Natl. Belg. 55: 298. 1985 - Holotype: [Georgia] Iberia, Tiflis, 1819, F.E.L. Fischer s.n. (G-DC barcode G00211736!).

= Vaccaria arvensis Link, Handbuch 2: 240. 1829, nom. illeg. (cited $V$. pyramidata Medik. in synonymy).

= Vaccaria sessilifolia Sweet, Hort. Brit., ed. 2.: 51. 1830, nom. illeg. (cited $V$. pyramidata Medik. in synonymy).

= Vaccaria oxyodonta Boiss., Diagn. Pl. Orient., ser. 2, 1: 68. $1854 \equiv$ Saponaria oxyodonta (Boiss.) Boiss., Fl. Orient. 1: 525. 1867 E Vaccaria pyramidata var. oxyodonta (Boiss.) Zohary, Fl. Palaestina 1: 104. 1966 EVaccaria hispanica subsp. oxyodonta (Boiss.) Greuter \& Burdet in Willdenowia 12: 191. 1982 - Lectotype (designated by Rechinger, F. Iranica 163: 339. 1988): Afghanistan, W. Griffith Herb. Late East Ind. Comp. 309 (G; isotype: C).

= Saponaria liniflora Boiss. \& Hausskn. in Boissier, Fl. Orient. 1: $525.1867 \equiv$ Vaccaria liniflora (Boiss. \& Hausskn.) Bornm. in Notizbl. Bot. Gart. Berlin-Dahlem 7: 142. 1917 $\equiv$ Vaccaria pyramidata var. liniflora (Boiss. \& Hausskn.) Cullen in Notes Roy. Bot. Gard. Edinburgh 27: 214. 1967 $\equiv$ Vaccaria hispanica subsp. liniflora (Boiss. \& Hausskn.) Greuter \& Burdet in Willdenowia 12: 191. 1982 =Vaccaria hispanica var. liniflora (Boiss. \& Hausskn.) J.Léonard in Bull. Jard. Bot. Natl. Belg. 55: 298. 1985 - Syntypes: [Turkey, C7] Inter segetes, inter Orfa et Karan, 1865, H.K. Haussknecht, Iter syriaco-armeniacum s.n. (or 542) (JE barcodes JE00015333!, JE00015334!, JE00015335! \& JE00015336!; isosyntype: K barcode K000725843!).

= Vaccaria perfoliata Halacsy, Consp. Fl. Graec. 1: 189. 1900, nom. illeg., non (Roxb. ex Willd.) Sweet 1830.

= Vaccaria brachycalyx Pau in Trab. Mus. Ci. Nat., Ser. Bot. 14: 10. 1918 - Type: [Iran, Prov. Khuzestan] Gotevend y Valle de Bazouft, bajo Karum, 400 m, Martinez de la Escalera s.n. (MA).

9. Heterochroa Bunge in Ledeb., Fl. Altaic. 2: 131. $1830 \equiv$ Gypsophila sect. Heterochroa (Bunge) A.Braun in Flora 26: 383. 1843. - Type: H. petraea Bunge.

Diagnosis. - Reniform-oblong seeds and narrow membranous commissures are the main characteristic features of this genus.

Description. - Perennial low herbs, or dense caespitose plants, mostly with thick roots, often glandular hairy; leaves very small, linear, linear-subulate, linear-lanceolate, lanceolate, or ovate; inflorescence dichasial, lax-dichasial, or solitary; calyx campanulate or widely campanulate, either with narrow or without membranous commissures and without calcium oxalate druses; petals 5, white to purple; stamens 10, often shorter than petals; styles 2; ovules 8-24; capsule opening by 4 valves; seeds reniform, slightly oblong; embryo curved; $2 n$ $=34,36$; species 6 .

Etymology. - From Greek hetero: different+chroa: skin, color of skin.

Distribution. - Kazakhstan (Turkestan), Russia (West Siberia; Altai; Far East, Kamchatka peninsula), Mongolia and N China.

Habitat. - On stony or rubble hills and alpine zones, or on stony semi-desert soils.

\section{Resurrected names}

Heterochroa desertorum Bunge in Mém. Acad. Imp. Sci. St.-Pétersbourg Divers Savans 2: 543. 1835 E Gypsophila desertorum (Bunge) Fenzl in Ledebour, Fl. Ross. 1: 292. 1842 - Holotype: [Russia, West Siberia], Altai, along the river Tshuya, 1832, A. Bunge s.n. (LE; isotype: P barcode P04980638!; possible isotypes: CAS barcode 00123503!, E barcode E00301730!, K barcode K000725758!, L barcode L 0038678 !).

Heterochroa microphylla Schrenk in Fischer \& Meyer, Enum. Pl. Nov. 1: 921841 - Holotype: [Kazakhstan] Alatau, Tarbagatai Mts., 1840, A.G. Schrenk s.n. (LE; isotypes: BR, P barcode P04980989!).

Heterochroa petraea Bunge in Ledebour, Fl. Altaic. 2: 131. $1830 \equiv$ Gypsophila petraea (Bunge) Fenzl in Ledebour, Fl. Ross. 1: 291. 1842, nom. illeg., non (Baumg.) Rchb. 1830 - Syntypes: [Russia: West Siberia], Altai, Baschkaus, 
A. Bunge s.n. (LE; possible isosyntypes: BR, E barcode E00301729!, G barcode G00226863!, HAL barcode HAL0117888!, K barcodes K000725762!, K000725763! \& K000725764!, M, P barcodes P04981532! \& P04981533!); prope Riddersk, collector? (LE).

Heterochroa violacea (Ledeb.) Walp., Repert. Bot. Syst. 5: 81. $1845 \equiv$ Gypsophila violacea (Ledeb.) Fenzl in Ledebour, Fl. Ross. 1: 291. $1842 \equiv$ Arenaria violacea Ledeb. in Mém. Acad. Imp. Sci. St. Pétersbourg Hist. Acad. 5: 533-534. 1815 - Holotype: [Russia, Far East], Okhotsk, Yablonov Mts, near the city Okhotsk, D. Redowsky s.n. (LE).

\section{New combinations}

Heterochroa antoninae (Schischk.) Madhani \& Zarre, comb. nov. $\equiv$ Gypsophila antoninae Schischk., Fl. URSS 6: 744. 1936; and in Trudy Bot. Inst. Akad. Nauk S.S.S.R., Ser. 1, Fl. Sist. Vyssh. Rast. 3: 180. 1937 - Holotype: Turkmenistan, Kopet Dag, Kyzyl Chasar, 27 Jun 1934, $A$. Borissova s.n. (LE).

$=$ Gypsophila porphyrantha Rech.f. \& Aellen in Bot. Jahrb. Syst. 75: 356. 1951 - Holotype: [Iran], Khorasan, Montes Hezar Masjed, inter Gash et Talqur, 1600-1800 m, 7-10 Jun 1948, K.H. Rechinger \& F. Rechinger, Iter Iranicum II, 5173 (W No. W 1960-0001226!; isotypes: G barcodes G00006044! \& G00006045!).

Heterochroa turkestanica (Schischk.) Madhani \& Zarre, comb. nov. $\equiv$ Gypsophila turkestanica Schischk. in Trudy Bot. Muz. 24: 38. 1932 - Holotype: [Russia], Middle Asia, Tien Shan, Alexandrov Mts., between the rivers Tshatshke and Terek, 20 Jul 1930, M. IIjin s.n. (LE).

10. Petroana Madhani \& Zarre, gen. nov. - Type: P. montserratii (Fern. Casas.) Madhani \& Zarre (三 Gypsophila montserratii Fern.Casas.).

Diagnosis. - It is similar to Gypsophila but differs in having spathulate and fleshy leaves as well as seeds with testa cells moderately polygonal (not elongated as in Gypsophila), swollen and tuberculate on periclinal walls.

Description. - Perennial herbs; leaves spathulate and fleshy, paired at each node, and sometimes condensed; flowers small, arranged in dichasial lax inflorescences; pedicel 4-6 mm long; calyx campanulate with membranous commissures; petals 5, concolorous, white to pinkish; stamens 10; ovary on a very short gynophore; ovules ca. 16; styles 2, stigma terminal; capsule opening by 4 valves; seeds subreniform, testa cells polygonal, swollen and tuberculate; embryo curved; $2 n=26$; species 2 .

Etymology. - Petro: rock+ana: pertaining.

Distribution. - The two members of this genus show a disjunct distribution pattern; $P$. montserratii is a mountainous element in the Iberian peninsula and P. montana is found in Yemen (N \& S), Socotra, Oman and Somalia.

Habitat. - Open rocky slopes and gravelly wadi-bed (for $P$. montana) and cracks in limestone, overhangs, and vertical walls (for $P$. montserratii).

\section{Included species}

Petroana montana (Balf.f.) Madhani \& Zarre, comb. nov. $\equiv$ Gypsophila montana Balf.f. in Proc. Roy. Soc. Edinburgh 11: 501. 1882 三 Saponaria montana (Balf.f.) Barkoudah in Wentia 9: 183. 1962 - Lectotype (designated here): Socotra, Feb-Mar 1880, Balfour, Cockburn \& Scott 442 (E barcode E00239367!; isolectotype: P barcode P05018082!).

Petroana montserratii (Fern.Casas) Madhani \& Zarre, comb. nov. $\equiv$ Gypsophila montserratii Fern.Casas in Publ. Inst. Biol. Aplicada 52: 121. 1972 - Holotype: Spain, Fuensanta nomen auclit, inter oppidula El-che de la Sierra et Yeste (Albacete), ubi lege1'Unt, 14 Jul 1971, J. Molero \& J. Fernandez Casas s.n. (GDA; isotypes: BC, BCC, BCF, JACA, MA barcode MA 327148!, SEV barcode SEV 9303!).

11. Petrorhagia (Ser.) Link, Handbuch 2: 235. $1831 \equiv$ Gypsophila sect. Petrorhagia Ser. in DC., Prodr. 1: 354. 1824 - Type (designated by Britton \& Brown, Ill. Fl. N.U.S., ed. 2, 2: 72. 1913): P. saxifraga (L.) Link.

= Imperatia Moench, Methodus: 60. 1794 - Type: I. filiformis Moench (三Petrorhagia saxifraga (L.) Link).

= Tunica Ludw., Inst. Regn. Veg., ed. 2: 129. 1757 - Type: T. saxifraga Scop. (三 Petrorhagia saxifraga (L.) Link).

= Kohlrauschia Kunth, Fl. Berol. 1: 108. 1838 EDianthus sect. Kohlrauschia (Kunth) Fenzl in Endlicher, Gen. P1.: 971. $1840 \equiv$ Petrorhagia sect. Kohlrauschia (Kunth) Ball \& Heywood in Bull. Brit. Mus. (Nat. Hist.), Bot. 3. 1964 Type: K. prolifera (L.) Kunth (三Petrorhagia prolifera (L.) P.W.Ball \& Heywood).

=Fiedleria Rchb., Deut. Bot. Herb.-Buch: 206. 1841 三 Tunica sect. Fiedleria (Rchb.) Graebn. in Ascherson \& Graebner, Syn. Mitteleur. F1. 5(2): 272. 1921 - Type: F. illyrica (Sm.) Rchb. (三 Petrorhagia illyrica (Ard.) P.W.Ball \& Heywood). Diagnosis. - Peltate seeds and a straight embryo along with membranous calyx commissures as well as the presence of an epicalyx in most members of Petrorhagia, separate it from Bolanthus, Dianthus, Gypsophila and Saponaria.

Description. - Annual, biennial, or perennial herbs, sometimes woody at base; leaves often narrow and grass-like, linear, subulate to oblong; flowers hermaphrodite or sometimes unisexual in panicles, capitate or fasciculate cymes, or solitary; bracts and bracteoles absent or present, when present often surrounding the calyx as an epicalyx; calyx campanulate, cylindrical or tubular, 5- to 15-veined, 5-toothed with broad membranous commissures; petals 5, white to pink or reddish-lilac; stamens 10; styles 2; capsule opening by 4 teeth; seeds numerous, peltate, dorsiventrally compressed, with facial hilum; embryo straight; $2 n=26,28,30$, or 60 ; species ca. 30 .

Etymology. - From the Greek petra: rock+rhagas: a chink or break.

Distribution - - Europe (Mediterranean region), C and SW Asia, Africa (Mediterranean region); introduced in North (with only four species being native) and South America, Africa (Republic of South Africa), Hawaii, Australia. 
Habitat. - These plants mostly grow in rocky cliffs of mountainous areas, calcareous or rocky substrates.

12. Psammophiliella Ikonn. in Novosti Sist. Vyssh. Rast. 11: 116. 1976 E Psammophila Fourr. ex Ikonn., Novosti Sist. Vyssh. Rast. 8: 273. 1971, nom. illeg., non Schult. 1822 Type: P. muralis (L.) Ikonn. (三 Gypsophila muralis L.).

- "Psammophila" Fourr. in Ann. Soc. Linn. Lyon, sér. 2, 16:

345. 1868, nom. nud., not validly published.

Diagnosis. - Roots more or less fibrillary (P. muralis), and the stigmatic surface extending along the inner side of the style are the diagnostic features of these species.

Description. - Annual herbs; leaves linear to lanceolate; flowers in lax dichasial cymes; bracts present; calyx campanulate or turbinate-tubular, with membranous or inconspicuously membranous commissures; petals 5, white or pink; stamens 10 , the stigmatic surface extending all along the style; styles 2; capsule opening by 4 teeth, oblong; seeds reniform, with flat tubercles; embryo curved; $2 n=(30), 34$; species 4 .

Etymology. - From Greek psammos: sand + philia: loving.

Distribution. - Central Asia; P. muralis is native to Europe and introduced to North America.

Habitat. - Sandy and calcareous hills, and sometimes ruderal environments (P. muralis).

13. Psammosilene W.C.Wu \& C.Y.Wu in King \& al., Icon. Pl. Medic. Libro Tien-Nan-Pen-Tsao Lanmaoano 1: [s.n.], t. 1. 1945 - Type: P. tunicoides W.C.Wu \& C.Y.Wu.

Diagnosis. - The membranous capsules in this genus are unique among the members of tribe Caryophylleae.

Description. - Perennial herbs, puberulous; leaves ovate, subsessile; flowers in terminal cymes; bracts leafy; calyx tubular, 15-veined and 5-toothed, densely glandular pubescent, veins green; petals 5 purple-violet, inconspicuously clawed; stamens 5; styles 2; ovary sessile, membranous, narrowly obovoid; ovules 2; capsule membranous, probably indehiscent, 1-seeded, enclosed by the persistent sepals; seeds peltate, embryo straight; species 1.

Etymology. - From Greek psammos: sand + Silene.

Distribution. - China (prov. Yunnan).

Habitat. - Rocky mountain slopes, dry pastures, calcareous rock crevices, forests.

14. Saponaria L., Sp. Pl.: 408. 1753 - Type (designated by Hitchcock \& Green in Sprague, Nom. Prop. Brit. Bot. 155. 1929): S. officinalis L.

= Bootia Neck., Delic. Gallo-Belg.: 193. 1768, nom. illeg., non Adans. 1763 = Saponaria sect. Bootia (Neck.) DC., Prodr. 1: 365.1824 - Type: B. vulgaris Neck. (三 Saponaria officinalis L.).

= Saponaria sect. Proteinia Ser. ex DC., Prodr. 1: 366.1824 三Proteinia (Ser. ex DC.) Rchb., Deut. Bot. Herb.-Buch: 205. 1841 - Type (designated by Schulz in Bot. Zhurn. (Moscow \& Leningrad) 69: 1479. 1984): Saponaria orientalis L.

=Spanizium Griseb., Spic. Fl. Rumel. 1: 180. 1843 - Type: S. ocymoides (L.) Griseb. (三 Saponaria ocymoides L.).
= Pleioneura Rech.f. in Bot. Jahrb. Syst. 75(3): 357. 1951 - Type: P. griffithiana (Boiss.) Rech.f. (三 Saponaria griffithiana Boiss.).

Diagnosis. - Distinctly clawed petals with coronal appendages separate the members of this genus from other related genera, i.e., Gypsophila.

Description. - Perennial or rarely annual herbs; leaves lanceolate to ovate or linear; inflorescence formed of lax or densely paniculate or capitate cymes, rarely solitary; bracts herbaceous, bracteoles absent; calyx tubular, obscurely 15- to 25-veined, without membranous commissures or with very narrow ones; petals 5 , mostly distinctly clawed, coronal scales usually present; stamens 10 ; styles 2 , rarely 3 ; ovary on a very short gynophore; ovules ca. 16; capsules opening by 4 , rarely 6 , teeth; seeds reniform-globular with a distinct hilum; embryo curved; $2 n=28,56$; species ca. 30 .

Etymology. - From the Latin sapo: soap.

Distribution. - Temperate Eurasia, mainly in the Mediterranean and Irano-Turanian regions, Mediterranean Africa; introduced to North and South America, India, and Australia .

Habitat. - Various habitats, sometimes on serpentine and calcareous soils.

\section{Resurrected name}

Saponaria griffithiana Boiss., Diagn. Pl. Orient., ser. 2, 1: 70. 1854 三Pleioneura griffithiana (Boiss.) Rech.f. in Bot. Jahrb. Syst. 75: 357. 1951 - Holotype: [Afghanistan], Afghania, 2100-3800 m, W. Griffith 1642 (G [herb. Boissier]; isotypes: K barcodes K000725812! \& K000725813!; possible isotypes [Griffith s.n. in Herb East India Co. 308]: C barcode C10009153!, GH barcode 00096746!, K barcode K000725815!, P barcode P05017981!, S No. S08-18!, W No. W 0047801!).

\section{aUTHOR CONTRIBUTIONS}

HM: Specimen study, plant collection, laboratory procedures, molecular analyses, manuscript preparation. RR: Nomenclatural research, manuscript revision, providing some references, comments on consensus trees, some taxonomic novelties in the study group. AP: Providing some sequences, commenting the manuscript. BO: Manuscript revision, providing some sequences. GH: Providing laboratory and technical facilities, providing some plant materials, manuscript revision. SZ: Supervising the study, manuscript revision. - HM, https://orcid.org/0000-0003-03609527, hossein.madhani@ut.ac.ir; RR,https://orcid.org/0000-0002-67650353, rabeler@umich.edu); AP, https://orcid.org/0000-0003-4937-5711, atefeh.pirani@gmai.com; BO, https://orcid.org/0000-0002-6104-4264, bengt.oxelman@bioenv.gu.se; GH, heubl@1rz.uni-muenchen.de; SZ, https://orcid.org/0000-0001-9159-1800, zarre@khayam.ut.ac.ir)

\section{aCKNOWLEDGEMENTS}

This paper presents some results of the project, entitled: Molecular phylogeny of Caryophylleae (Caryophyllaceae), supported partly 
by the Iran National Science Foundation (INSF, grant number 96003422). HM is grateful to the University of Tehran for supporting his master thesis on Caryophylleae. We are grateful to the curators of the herbaria B, G, LE, M, MSB, TUH, W and WU for their generous assistance, giving us the opportunity to study sheets of this plant group and remove samples for DNA extraction. SZ also appreciates financial supports provided by Alexander Humboldt Stiftung (Germany) as well as University of Tehran. Nicholas Turland (B) and Kanchi Gandhi (GH) provided nomenclatural assistance. James Solomon (MO) kindly provided a copy of Phitos (1981). We are grateful to the editors and reviewers handling this manuscript who helped us to improve the methodology, taxonomic treatments as well as linguistic errors.

\section{- LITERATURE CITED}

Amini, E., Zarre, S. \& Assadi, M. 2011. Seed micro-morphology and its systematic significance in Gypsophila (Caryophyllaceae) and allied genera. Nordic J. Bot. 29: 1-10. https://doi.org/10.1111/j.1756-1051.2011.01208.x

Ball, P.W. \& Heywood, V.H. 1964. A revision of the genus Petrorhagia. Bull. Brit. Mus. (Nat. Hist.) Bot. 3: 119-172.

Barkoudah, Y.I. 1962. A revision of Gypsophila, Bolanthus, Ankyropetalum and Phryna. Wentia 9: 1-203. https://doi.org/10.1111/j.1438-8677.1962.tb00012.x

Bentham, G. \& Hooker, W.G. 1862. Genera plantarum, vol. 1(1). Londini [London]: venit apud A. Black, etc. https://doi.org/10.5962/bhl.title.747

Bittrich, V. 1993. Caryophyllaceae. Pp. 206-236 in: Kubitzki, J., Rohwer, J.G. \& Bittrich, V. (eds.), The families and genera of vascular plants, vol. 2. Berlin: Springer. https://doi.org/10.1007/978-3-662-02899-5_21

Boissier, E. 1867. Flora orientalis, vol. 1. Basileae [Basel]: apud H. Georg. https://doi.org/10.5962/bhl.title.20323

Candolle, A.P. de 1824. Prodromus systematis naturalis regni vegetabilis, pars 1. Parisiis [Paris]: sumptibus sociorum Treuttel et Würtz. https://doi.org/10.5962/bhl.title.286

Dillenberger, M.S. \& Kadereit, J.W. 2014. Maximum polyphyly: Multiple origins and delimitation with plesiomorphic characters require a new circumscription of Minuartia (Caryophyllaceae). Taxon 63: 64-88. https://doi.org/10.12705/631.5

Eig, A. 1931. Les éléments et les groupes phytogéographiques auxiliaires dans la flore palestinienne: Etude phytogéographique. Dahlem bei Berlin: Verlag des Repertoriums.

Fenzl, E. 1840 (“1836-1840”). Subordo IV. Sileneae DC. Pp. 970-974 in: Endlicher, S. (ed.) Genera plantarum secundum ordines naturales disposita. Vindobonae [Vienna]: apud Fr. Beck. https://doi.org/10.5962/bhl.title.728

Fior, S., Karis, P.O., Casazza, G., Minuto, L. \& Sala, F. 2006. Molecular phylogeny of the Caryophyllaceae (Caryophyllales) inferred from chloroplast mat $K$ and nuclear rDNA ITS sequences. Amer. J. Bot. 93: 399-411. https://doi.org/10.3732/ajb.93.3.399

Greenberg, A.K. \& Donoghue, M.J. 2011. Molecular systematics and character evolution in Caryophyllaceae. Taxon 60: 1637-1652.

Grisebach, A.H.R. 1843. Spicilegium florae rumelicae et bithynicae, vol. 1. Brunsvigae [Braunschweig]: prostat apud Fridericum Vieweg et filium.

Haller, A. von 1742. Enumeratio methodica stirpium Helvetiae indigenarum, vol. 1. Gottingae [Göttingen]: ex officina academica Abrami Vandenhoek. http://bibdigital.rjb.csic.es/ing/Libro.php?Libro $=2860$

Harbaugh, D.T., Nepokroeff, M., Rabeler, R.K., McNeill, J., Zimmer, E.A. \& Wagner, W.L. 2010. A new lineage-based tribal classification of the family Caryophyllaceae. Int. J. Pl. Sci. 171: 185-198. https://doi.org/10.1086/648993

Hernández-Ledesma, P., Walter, G., Berendsohn, W.G., Borsch, T., Mering, S. von, Akhani, H., Arias, S., Castañeda-Noa, I., Eggli, U., Eriksson, R., Flores-Olvera, H., Fuentes-Bazán, S., Kadereit, G., Klak, C., Korotkova, N., Nyffeler, R., Ocampo, G., Ochoterena, H., Oxelman, B., Rabeler, R.K., Sanchez, A., Schlumpberger, B.O. \& Uotila, P. 2015. A taxonomic backbone for the global synthesis of species diversity in the angiosperm order Caryophyllales. Willdenowia 45: 281-383. https://doi.org/10.3372/wi.45.45301

Huson, D.H. \& Scornavacca, C. 2012. Dendroscope 3: An interactive tool for rooted phylogenetic trees and networks. Syst. Biol. 61: 1061-1067. https://doi.org/10.1093/sysbio/sys062

Ikonnikov S.S. 1976. Notae de Caryophyllaceis, 3. Novosti Sist. Vyssh. Rast. 13: 113-117. [In Russian]

Ikonnikov, S.S. 2004. Two new genera of the family Caryophyllaceae from Afghanistan. Bot. Zhurn. 89: 114-116. [In Russian]

Jakovljević, K., Lakušić, D., Vukojičić, S., Tomović, G., ŠinžarSekulić, J. \& Stevanović, V. 2011. Richness and diversity of Pontic flora on serpentine of Serbia. Centr. Eur. J. Biol. 6: 260274. https://doi.org/10.2478/s11535-010-0110-5

Kadereit, J.W., Albach, D.C., Ehrendorfer, F., Galbany-Casals, M., Garcia-Jacas, N., Gehrke, B., Kadereit, G., Kilian, N., Klein, J.T., Koch, M.A. \& Kropf, M. 2016. Which changes are needed to render all genera of the German flora monophyletic? Willdenowia 46: 39-91. https://doi.org/10.3372/wi.46.46105

Katoh, K. \& Standley, D.M. 2013. MAFFT multiple sequence alignment software version 7: Improvements in performance and usability. Molec. Biol. Evol. 30: 772-780. https://doi.org/10.1093/molbev/mst010

Kearse, M., Moir, R., Wilson, A., Stones-Havas, S., Cheung, M., Sturrock, S., Busxton, S., Cooper, A., Markowitz, S., Duran, C., Thierer, T., Ashton, B., Mentjies, P. \& Drummond, A. 2012. Geneious Basic: An integrated and extendable desktop software platform for the organization and analysis of sequence data. Bioinformatics 28: 1647-1649.

Kemler, M., Martín, M.P., Telleria, M.T., Schäfer, A.M., Yurkov, A. \& Begerow, D. 2013. Contrasting phylogenetic patterns of anther smuts (Pucciniomycotina: Microbotryum) reflect phylogenetic patterns of their caryophyllaceous hosts. Organisms Diversity Evol. 13: 111-126. https://doi.org/10.1007/s13127-012-0115-1

Kool, A., Perrigo, A. \& Thulin, M. 2012. Bristly versus juicy: Phylogenetic position and taxonomy of Sphaerocoma (Caryophyllaceae). Taxon 61: 67-75.

Linnaeus, C. 1753. Species plantarum, vol. 1. Holmiae [Stockholm]: impensis Laurentii Salvii. http://dx.doi.org/10.5962/bhl.title.669

Löve, Á. 1973. IOPB chromosome number reports XLII. Taxon: 647-654.

Ludwig, C.G. 1757. Institutiones historico physicae regni vegetabilis, ed. 2. Lipsiae [Leipzig]: apud Ioh. Fridericum Gleditsch. https://doi.org/10.5962/bhl.title.112554

Maddison, W.P. \& Maddison, D.R. 2011. Mesquite: A modular system for evolutionary analysis, version 2.75 . http://mesquiteproject.org/

Marin, P.D. \& Tatić, B. 2001. Serpentine soil and plant diversity with emphasis of Balkan Peninsula. Bocconea 13: 145-150.

McNeill, J., Barrie, F.R., Buck, W.R., Demoulin, V., Greuter, W., Hawksworth, D.L., Herendeen, P.S., Knapp, S., Marhold, K., Prado, J., Prud'homme van Reine, W.F., Smith, G.F., Wiersema, J.H., \& Turland, N.J. (eds.) 2012. International Code of Nomenclature for algae, fungi, and plants (Melbourne Code). Regnum Vegetabile 154. Königstein: Koeltz Scientific Books.

Miller, A.G. \& Cope, T.A. 1996. Flora of the Arabian Peninsula and Socotra, vol. 1. Edinburgh: Edinburgh University Press,

Miller, M.A., Pfeiffer, W. \& Schwartz, T. 2010. Creating the CIPRES Science Gateway for inference of large phylogenetic trees. Pp. 45-52 in: Proceedings of the Gateway Computing Environments 
Workshop (GCE), New Orleans, Louisiana, 14 Nov 2010. Piscataway: IEEE. https://doi.org/10.1109/GCE.2010.5676129

Oxelman, B., Lidén, M. \& Berglund, D. 1997. Chloroplast rps16 intron phylogeny of the tribe Sileneae (Caryophyllaceae). Pl. Syst. Evol. 206: 393-410. https://doi.org/10.1007/BF00987959

Pax, F. \& Hoffmann, K. 1934. Caryophyllaceae. Pp. 275-364 in: Engler, A. \& Harms, H. (eds.), Die natürlichen Pflanzenfamilien, ed. 2, vol. 16c. - Leipzig: Engelmann.

Petri, A. \& Oxelman, B. 2011. Phylogenetic relationships within Silene (Caryophyllaceae) section Physolychnis. Taxon 60: 953-968.

Phitos, D. 1981. The genus Bolanthus (Caryophyllaceae) in Greece. Bot. Chron. (Patras) 1: 35-45.

Pirani, A., Zarre, S., Pfeil, B.E., Bertrand, Y.J.K., Assadi, M. \& Oxelman, B. 2014. Molecular phylogeny of Acanthophyllum (Caryophyllaceae: Caryophylleae), with emphasis on infrageneric classification. Taxon 63: 592-607. https://doi.org/10.12705/633.39

Posada, D. 2008. jModelTest: Phylogenetic model averaging. Molec. Biol. Evol. 25: 1253-1256. https://doi.org/10.1093/molbev/msn083

Poyraz, İ.E. \& Ataşlar, E. 2010. Pollen and seed morphology of Velezia L. (Caryophyllaceae) genus in Turkey. Turk. J. Bot. 34: 179-190.

Rabeler, R.K. 1984. Notes on nomenclature within Petrorhagia (Caryophyllaceae). Taxon 33: 714-716. https://doi.org/10.2307/1220793

Rabeler, R.K. 1993. Infrageneric nomenclature: Corrections and additions in the Caryophyllaceae. Contr. Univ. Michigan Herb. 19: 149-164.

Rabeler, R.K. \& Bittrich, V. 1993. Suprageneric nomenclature in the Caryophyllaceae. Taxon 42: 857-863. https://doi.org/10.2307/1223270

Rambault, A., Suchard, M.A., Xie, D. \& Drummond, A.J. 2014. Tracer, version 1.60. http://beast.bio.ed.ac.uk/tracer

Rechinger, K.H. 1988. Gypsophila. Pp. 206-246 in: Rechinger, K.H., Melzheimer, V., Möschl, W. \& Schiman-Czeika, H., Flora Iranica, vol. 163, Caryophyllaceae II. Graz: Akademische Drucku. Verlagsanstalt.

Reeve, H., Coode, M.J.E., Cullen, J., Hedge, I.C. \& Huber-Morath, A. 1967. Caryophyllaceae Group V. Pp. 99-179 in: Davis, P.H. (ed.), Flora of Turkey and the East Aegean Islands, vol. 2. Edinburgh University Press.

Ronquist, F. \& Huelsenbeck, J.P. 2003. MrBayes 3: Bayesian phylogenetic inference under mixed models. Bioinformatics 19: 1572-1574. https://doi.org/10.1093/bioinformatics/btg180

Sadeghian, S., Zarre, S., Rabeler, R.K. \& Heubl, G. 2015. Molecular phylogenetic analysis of Arenaria (Caryophyllaceae: tribe Arenarieae) and its allies inferred from nuclear DNA internal transcribed spacer and plastid DNA rps16 sequences. Bot. J. Linn. Soc. 178: 648-669. https://doi.org/10.1111/boj.12293

Schischkin, B.K. 1936. Caryophyllaceae (Diantheae). Pp. 555-660 in: Komarov, V.L. (ed.), Flora of the U.S.S.R., English translation 1970, vol. 6. Leningrad: Izdatel'stvo Akademii Nauk SSSR Moskva.

Scopoli, J.A. 1771 (“1772”). Flora carniolica, ed. 2, vol. 1. Vindoboniae [Vienna]: impensis Joannis Pauli Krauss. http://bibdigital.rjb.csic.es/ing/Libro.php?Libro $=982$

Shults, V.A. 1989. Rod myl'nyanka (Saponaria L. s.l.) vo flore SSSR. Riga: Zinatne.

Simmler, G. 1910. Monographie der Gattung Saponaria. Denkschr. Kaiserl. Akad. Wiss. Wien., Math.-Naturwiss. Kl. 85: 433-509.

Šourková, M. 1978. Caryophyllaceae subfam. Dianthoideae - Begrenzung, Charakteristik, und Gliederung. Preslia 50: 139-152.

Stamatakis, A. 2014. RAxML version 8: A tool for phylogenetic analysis and post-analysis of large phylogenies. Bioinformatics 30: 1312-1313. https://doi.org/10.1093/bioinformatics/btu033

Strid, A. 1986. Mountain flora of Greece, vol. 1. Cambridge: Cambridge University Press.

Swofford, D.L. 2003. PAUP*: Phylogenetic analysis using parsimony (*and other methods), version $4.0 \mathrm{~b} 10$ for 32-bit Microsoft Windows. Sunderland (Massachusetts): Sinauer.

Tutin, T.G., Burges, N.A., Chater, A.O., Edmonson, J.R., Heywood, V.H., Moore, D.M., Valentine, D.H., Walters, S.M. \& Webb, D.A. 1964. Flora Europaea, vol. 1. Cambridge: Cambridge University Press.

Valente, L.M., Savolainen, V. \& Vargas, P. 2010. Unparalleled rates of species diversification in Europe. Proc. Roy. Soc. London, Ser. B, Biol. Sci. 277: 1489-1496. https://doi.org/10.1098/rspb.2009.2163

Vargas, P., Baldwin, B.G. \& Constance, L. 1998. Nuclear ribosomal DNA evidence for a western North American origin of Hawaiian and South American species of Sanicula (Apiaceae). Proc. Natl. Acad. Sci. U.S.A. 95: 235-240. https://doi.org/10.1073/pnas.95.1.235

Vítová, J., Vít, P. \& Suda, J. 2015. Rare occurrence of reciprocal hybridization in a sympatric population of the Czech stenoendemic Dianthus arenarius subsp. bohemicus and widespread D. carthusianorum. Preslia 87: 329-345.

White, T.J., Bruns, T., Lee, S. \& Taylor, J. 1990. Amplification and direct sequencing of fungal ribosomal RNA genes for phylogenetics. Pp. 315-322 in: Innis, M.A., Gelfand, D.H., Sninsky, J.J. \& White, T.J. (eds.), PCR protocols: A guide to methods and applications. San Diego: Academic Press. https://doi.org/10.1016/B978-0-12-372180-8.50042-1

Appendix 1. Voucher information: species name, geographical origin, collector(s), voucher (herbarium), GenBank accession numbers for ITS and rps16, respectively (* indicates sequences new for this study). Species names follow the taxonomic treatment suggested in the present study. Voucher data are given only for accessions used in generating new sequences or those generated previously by our team (Pirani \& al., 2014).

Acanthophyllum aphananthum Rech.f. 1, Afghanistan, Kabul, Rechinger 31265 (M), KF924626, KF924681; Acanthophyllum aphananthum 2, Afghanistan,

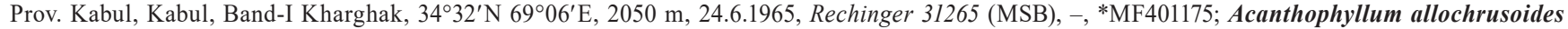
(Gilli) A.Pirani 1, Afghanistan, Bamian, Wendelbo \& Ekberg W9801 (GB), KF924627, KF924682; Acanthophyllum allochrusoides 2, Afghanistan, Prov. Baghlan, Andarab-Tal, Fuß des Koh-e Shindadara bei Shashan (NE von Deh Salah), 1900-2000 m, 3547'N 69²1'E, 28.5.1972, O. Anders 9367 (MSB), -, *MF401172; Acanthophyllum borsczowii Litv., Iran, Khorassan, Zarre \& al. 41034 (TUH), KF924675, KF924727; Acanthophyllum bungei (Boiss.) Trautv. 1, Iran, E Azarbaijan, Rechinger 43834 (M), KF924634, KF924688; Acanthophyllum bungei 2, Turkey, A9 Kars, Kaĝizman-Tuzluça, 13 km W Tuzluça, 1060 m, 30.7.1984, Nydegger 19519 (MSB), *MF401121, *MF401169; Acanthophyllum cerastioides (D.Don) Madhani \& Zarre 1, Pakistan, Hazar, Ewald \& Zetterlund 6227 (GB), KF924628, -; Acanthophyllum cerastioides 2, NW Pakistan, Swat, in valle Jabba E Kolalai, substr. Granit, 1600-2200 m, 4.6.1965, Rechinger 30724 (M), *MF401122, *MF401168; Acanthophyllum grandiflorum Stocks, Afghanistan, Bamian, Podlech 1340 (MSB), KF924666, KF924718; Acanthophyllum herniarioides (Boiss.) Madhani \& Zarre, Tajikistan, N von Dushanbe Anzob-Pass im Gissar-Massiv, ca. 3400 m, 14.7.1975, MuellerDoblies 75083 (B), *MF401123, -; Acanthophyllum honigbergeri (Fenzl) Barkoudah, E Afghanistan, Gardes, in altoplanitie lapidosa vallis Logar 50 km

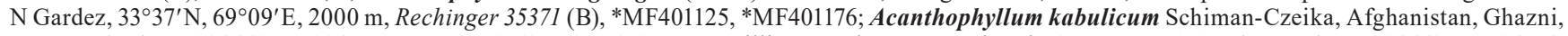
Frey s.n. (GB), KF924663, KF924715; Acanthophyllum kandaharicum Gilli, Iran, Khorassan, Joharchi \& Zangouei 36245 (FUMH), KF924662, KF924714; Acanthophyllum laxiflorum Boiss., Afghanistan, Lugar, Ekberg W9184 (GB), *KF924659, *KF924711; Acanthophyllum mucronatum C.A.Mey. 1, Iran,

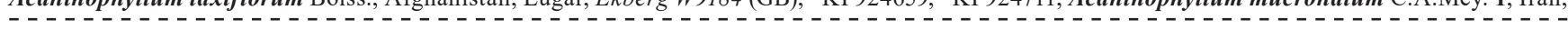


Appendix 1. Continued.

W Azarbaijan, Assadi \& Olfat 68668 (TARI), KF924652, KF924705; Acanthophyllum mucronatum 2, Armenia, Vayotsdzor Prov., Yeghegnadzor, vicinity of Agarakadzor village, Azar gorge, 1320 m, 26.6.2002, Optima Iter XI/2050 (M), -, *MF401170; Acanthophyllum myrianthum (Rech.f.) Madhani \& A.Pirani, C Afghanistan, Deh Kundi: in saxosis $10 \mathrm{~km}$ w Shahrestan, $33^{\circ} 40^{\prime} \mathrm{N}, 66^{\circ} 35^{\prime} \mathrm{E}$, versus Deh Kundi, $34^{\circ} 10^{\prime} \mathrm{N} 66^{\circ} 07^{\prime} \mathrm{E}, 2200 \mathrm{~m}, 1967$, Rechinger 36812 (B), *MF401124, -; Acanthophyllum oppositiflorum Aytaç, Turkey, Sivas, Aytaç 7476 (GAZI), KF924651, KF924704; Acanthophyllum scapiflorum (Akhtar) Schiman-Czeika, Afghanistan, Kabul, Podlech 31232 (MSB), KF924646, KF924699; Acanthophyllum sordidum Bunge ex Boiss., Iran, Isfahan, Pirani \& Moazzeni 2147 (TMRC), KF924644, KF924697; Acanthophyllum spinosum C.A.Mey., Iran, Isfahan, Pirani \& Moazzeni 2150 (TMRC), KF924642, KF924696; Acanthophyllum stocksianum Boiss., Afghanistan, Kandahar, Toncev s.n. (MSB), KF924639, KF924693; Acanthophyllum versicolor Fisch. \& C.A.Mey., Turkey, Kars, Nydegger 43597 b (MSB), KF924633, KF924687; Arenaria serpylloides Gay, KP148897, KP148997; Balkana spergulifolia (Griseb.) Madhani \& Zarre, Serbia, Altserbien, Zlatibor, südlich von Kremna, Umgebung von Gaj, Cigota Höhen, 1020-1475 m, 15.9.2004, Kalheber 041558 (M), *MF401126, *MF401185; Bolanthus cherlerioides (Bornm.) Bark., Turkey, B3 Isparta, Akşehir-Şarkikaraağaç, 5.1 km NE Örkenez an der Paßauffahrt, Schutt, 1480 m, 12.8.1975, K.P. \& E. Buttler 19986 (M), *MF401128, *MF401183; Bolanthus confertifolius (Hub.-Mor.) Madhani \& Heubl, Turkey, Antalya, between Fethiye and Kalkan, Pinus brutia forest, ca. 200 m, 5.2002, Özkan Eren 4362 (B), *KX834007, -; Bolanthus huber-morathii Simon, Turkey, A2 Bursa, Soĝkpinar-Keles, 4 km nach Soĝukpinar, 860 m, 5.7.1980, Nydegger 15138 (MSB), *KX834006, *MF401184; Bolanthus minuartioides (Jaub. \& Spach) Hub.-Mor., Turkey, Denizli, Muğla, 6.6.1955, Walter 201 (B), *KX834005, -; Bolanthus ortegioides (Fisch. \& C.A.Mey.) Madhani \& Rabeler, Turkey, B5 Kayseri, above Talas, Ağida mt., $1700 \mathrm{~m}, 8.8 .1997$, Zarre 42 (MSB), *KX834008, *MF401182; Cerastium fontanum Baumg., AY936241, FJ404899; Cyathophylla chlorifolia (Poir.) Bocquet \& A.Strid, Turkey, C3 Antalya, SW Anatolien, offener Steinschutt über Salikent, 2050 m, Exp. N, 2.9.1995, Ulrich s.n. (M), -, *MF401186; Cyathophylla viscosa (C.A.Mey.) Madhani \& Rabeler, Armenia, Vayotsdzor Prov., Vajk Distr, road Vajk-Kochbek, ca. 8 km ENE Vajk, gorge of Darab river, $1380 \mathrm{~m}$, sandy area, $1380 \mathrm{~m}, 26.6 .2002$, Optima Iter XI/1846 (M), *MF401117, *MF401165; Dianthus andrzejowskianus Kulcz., JN589032,-; Dianthus armeria L., JN589087, FJ404903; Dianthus candicus (Ball \& Heywood) Madhani \& Heubl, Greece, Ep. Sfakia, in declivibus australibus montis Akones ad orientem pagi Imvros, 1100-1150 m, 8.10.1966, Greuter 7679 (M), -, *MF401178; Dianthus carthusianorum L., EF407941, EF674194; Dianthus chinensis L., JN589157, -; Dianthus cyri Fisch. \& C.A.Mey., GU440808, -; Dianthus deltoides L., JN589027, -; Dianthus recticaulis Ledeb., Armenia, Vayotsdzor Prov., Yeghegnadzor Distr., ca. $12 \mathrm{~km}$ N Yeghegnadzor, around village Eghegis, $1540 \mathrm{~m}$, $45^{\circ} 22^{\prime} \mathrm{E}, 39^{\circ} 52^{\prime} \mathrm{N}$, humid meadows along river, forest with Quercus macranthera, dry slopes and rocks, 27.6.2002, Fayvush \& al., OPTIMA Iter XI/2199 (M), -, *MF401177; Dianthus tunicoides (Ser.) Madhani \& Heubl,, Greece, Chios, ca. 2 km nordöstlich Volissos am Rand der Straße nach Potamia, Grauwacke, 200 m, 16.6.1966, Lüdtke 581 (M), *MF401129, *MF401179; Diaphanoptera afghanica Podlech, Afghanistan, Baghlan, Podlech 21075 (MSB), KF924632, -; Diaphanoptera ekbergii Hedge \& Wendelbo 1, Afghanistan, Takhar, Podlech 11848 (MSB) \& 11760 (MSB), KF924631, KF924686; Diaphanoptera ekbergii 2, Afghanistan, Prov. Takhar, Khost-o-Fereng, oberes Khaush-Tal, Granitfelsen, 3800 m, 11.7.1965, Podlech 11760 (MSB), -, *MF401173; Diaphanoptera lindbergii Hedge \& Wendelbo, Afghanistan, Fariab, Hedge \& al. W8336 (GB), KF924630, KF924685; Diaphanoptera stenocalycina Rech.f. \& Schiman-Czeika 1, Iran, Golestan, Attar \& Mehdigholi 24422 (TUH), KF924629, KF924684; Diaphanoptera stenocalycina 2, Iran, Prov. Golestan, Golestan National Park, Almeh, 1600 m, 19.5.1975, Firuznia 1174 (M), -, *MF401174; Eremogone aculeata (S.Watson) Ikonn., JN589018, FJ404882; Eremogone picta (Sm.) Dillenb. \& Kadereit, KP148933, KP149035; Graecobolanthus fruticulosus (Bory \& Chaub.) Madhani \& Zarre, Greece, Insula Euboea septentrionalis, in saxosis serpentinicis et manesiticis ad litus a pago Mantudi orientem versus, 30.6.1958, Rechinger 19439(M), -, *MF401180; Graecobolanthus graecus (Schreb.) Madhani \& Rabeler, Greece, Epirus, Tal des Venetikos nördlich Eleftherokhori, an der Straße Kalambaka-Grevena, $500 \mathrm{~m}, 11.10 .1975$, Merxmüller \& Podlech 31173 (MSB), *KX834004, *MF401181; Gypsophila acantholimoides Bornm., Iran, Kuh-i Karkas (Kuh-i Kargiz), in declivibus supra Tar, 2300-2500 m, 27.5.1974, Rechinger 46581 (MSB), *MF401083, *MF401141; Gypsophila acutifolia Fisch., Russia, Podkumok-Tal bei Kislovodsk, 21.7.1967, Quasdorf 67 (B), *MF401100, *MF401156; Gypsophila antari Post, Iraq, Distr. Basra, Desertum meridionale (Southern Desert) Jabal Sanam, ca. $30^{\circ} 10^{\prime} \mathrm{N}, 47^{\circ} 30^{\prime} \mathrm{E}, 18.3 .1967$, Rechinger 8568 (M), *MF401089, *MF401134; Gypsophila arabica Barkoudah, Israel, Negev Highlands: Makhtesh Hazera (Makhtesh Katan), sandy alluvium, pebbly wadis and limestone outcrops, Altim. 10 m, 10.3.1989, Danin \& al. 35.036 (B), *MF401082, -; Gypsophila aretioides Boiss., Iran, Gachsar, Hezar Band mountain, alt. 3200 m, 30.7.2015, 36 $03^{\prime} \mathrm{N} 51^{\circ} 17^{\prime} \mathrm{E}$, Madhani 47116 (TUH), *MF401090, -; Gypsophila arrostii Guss, JN589043,-; Gypsophila arrostii var. nebulosa (Boiss. \& Heldr.) Greuter \& Burdet, Turkey, C3 Afyon, Isparta-Denizli, 21 km SE Dinar, 990 m, 5.8.1978, Nydegger 13410 (MSB), -, *MF401155; Gypsophila aucheri Boiss. 1, JN589077, -; Gypsophila aucheri 2, Turkey, B8 Erzincan, Erzerum und Tercan, $18 \mathrm{~km}$ östlich Tercan), $1860 \mathrm{~m}$, Steilbord, 2.8.1983, Nydegger 18633 (MSB), *MF401098, *MF401147; Gypsophila bermejoi G.Lopez, Spain, Prov. Segovia, Vallelado, UTM 30t UL 78, alt. 750 m, 26.8.1983, Ladero \& Casaseca 12107 (B), *MF401106, -; Gypsophila bicolor Grossh., JN589151, -; Gypsophila bicolor, Iran, Prov. Ghazvin, Abgarm to Avaj, $12 \mathrm{~km}$ to Avaj, $1 \mathrm{~km}$ to tunnel, beside the road, 1420-1500 m, 10.5.2004, Zarre, Mashayekhi, Taeb, Pirani \& Moazzeni 35136 (MSB), -, *MF401149; Gypsophila bucharica B.Fedtsch. 1, JN589057, -;Gypsophila bucharica 2, Tadzhikistania, jugum Chodzha-Kazian, declivibus australis montis Koipioztau, 1000 m, 8.5.1976, Kinzikaeva \& Koczkareva 6663 (M), *MF401102, *MF401162; Gypsophila capillaris (Forssk.) C.Chr. 1, KJ021878, -; Gypsophila capillaris 2, Egypt, Sinai Peninsula, Jebel Maghara, 8 km N of Bir el Hamma, $270 \mathrm{~m}$, siliceous rocks and flats, $33^{\circ} 30^{\prime} \mathrm{E}, 30^{\circ} 40^{\prime} \mathrm{N}, 3.5 .1991$, Podlech 50067 (MSB), *MF401092, *MF401135; Gypsophila capitata M.Bieb., Russia: Caucasus, Dagestan, Distr. Chunzach, inter pag, Golotl et Kachib, vallis fl. Avarskyi Koissu, 17.7.1961, Tzvelev, Czerepanov, Bobrov \& Dogadova 7559 (B), *MF401103, *MF401161; Gypsophila capituliflora Rupr. 1, JN589143, -; Gypsophila capituliflora 2, Tadzhikistan: Pamir orientalis, Czeczekty, prope Stationem Biologicam, fundus siccus valleculae, 3850 m, 21.8.1959, Ikonnikov 4365 (M), *MF401111, *MF401157; Gypsophila cephalotes (Schrenk) F.N.Williams 1, JN589105,-; Gypsophila cephalotes 2, Afghanistan, Prov. Badakhshan, Wakhan, unteres Waghjir Tal bis Zemestan-e Tikili, $37^{\circ} 06^{\prime} \mathrm{E}, 74^{\circ} 05^{\prime} \mathrm{N}, 3950-400 \mathrm{~m}$, 21.7.1971, Anders 7613 (MSB), *MF401105, *MF401158; Gypsophila curvifolia Fenzl 1, JN589159, -; Gypsophila curvifolia 2, Turkey, C4 Antalya, Orta Toroslar, zwischen Anamur und Kazanci, Friedhof bei Akpinar, Hügel aus (Kreide-)Kalk, offene Ruderalflur, $1630 \mathrm{~m}, 36^{\circ} 20^{\prime} \mathrm{N}, 32^{\circ} 50^{\prime} \mathrm{E}, 22.7 .1992$, P. Hein $^{\circ}$ 52-2 (B), *MF401099, *MF401159; Gypsophila elegans M.Bieb. 1, JN589130,-;Gypsophila elegans 2, Iran, Prov. Azarbaijan Sharqi, $19 \mathrm{~km}$ SE of Asheeqli (Asheglou) in the Aras valley at road to Kaleibar, Arasbaran Protected Area, $1850 \mathrm{~m}, 46^{\circ} 48^{\prime} 55^{\prime \prime} \mathrm{E}, 3^{\circ} 53^{\prime} 54^{\prime \prime} \mathrm{N}, 1850 \mathrm{~m}, 20.6 .2001$, Podlech \& Zarre 55293 (MSB), -, *MF401143; Gypsophila elegans 3, Germany, Bayern, Oberpfalz, Weiden, Mülldeponie/Bauschuttdeponie, offene Erde, 410-420 m, MTB 6338/2, 28.8.1991, Weigend 1895 (M), *MF401081, *MF401144; Gypsophila fastigiata L. 1, JN589144, -; Gypsophila fastigiata 2, Germany, Rheinland-Pfalz, Rheinhessen, Mainz, Autobahnböschung am NSG Großer Sand, 17.7.1988, Kalheber 88-2892 (M), *MF401097, *MF401152; Gypsophila globulosa Stev. Russia, Caucasica, Pjatigorsk, Felshügel über den Mineralquellen, ca. 4-500 m 11.7.64, Köhler (61) Bm 4306210 (B), *MF401108, -; Gypsophila glomerata Pall. ex M.Bieb., Bulgaria, Bezirk Kolarovgrad, Kalkfelsen bei Madara, 17.8.1968, Merxmüller \& Zollitsch 24599 (M), *MF401109, -; Gypsophila gypsophiloides (Fenzl) Blakelock, Iran, Prov. Luristan, Dow Rud, in declivibus aridis ad intoritum faucium fluvii Dez, substr. Calc., 1500-1600 m, 17.6.1974, Rechinger 48149 (M), *MF401086, *MF401138; Gypsophila heteropoda Freyn 1, JN589110, -; Gypsophila heteropoda 2, Georgia, Caucasus, peripheria urbis Tbilisi, haud procul a lacu Lisi, Alt. 600 m s. m., 17.5.1985, Vašák s.n. (B), *MF401085, -; Gypsophila laricina Schreb., Turkey, C5 Adana, Aladaglari, Kayacik Deresi, entrance to Narpiz Bogazi gorge, northern slope, alt. 2450 m, 7.8.1999, Doring, Parolly \& Tolimir 1231 (B), *MF401112, *MF401145; Gypsophila leioclada Rech.f., Iran, Prov. Azarbaijan Sharqi, near At Darrehsi, ca. $70 \mathrm{~km}$ SE Bostanabad toward Mianeh, 1434 m, 47 $23^{\circ} 23^{\prime \prime} \mathrm{E}, 37^{\circ} 30^{\prime} 54^{\prime \prime} \mathrm{N}$, 18.6.2001, Podlech \& Zarre 55219 (MSB), *MF401104, *MF401148; Gypsophila linearifolia (Fisch. \& C.A.Mey.) Boiss., Iran, Prov. Ilam, 36 km from Dehloran towards Mehran, gypsum hills, Pteropyrum community, 320 m, 4.5.1992, Akhani 8509 (MSB), *MF401091, *MF401136; Gypsophila nabelekii Schischk., Iran, Azerbaijan occidentalis, in monte Chalil Kuh prope Razhan, 2600-3200 m, 1974, Rechinger 48847 (B), *MF401088, *MF401142; Gypsophila oblanceolata Bark., Turkey, Provinz Nigde, bei Eregli nordlich von Ulukila, 1150 m ü. m., Steppe, Bodenoberfläche mit Trockenrissen und Salzabscheidungen, 27.9.1984, Hagemann, Binder \& Schwarz 2144 (B), *MF401115, *MF401160; Gypsophila sp. (Fisch. \& C.A.Mey.) Boiss., Turkey, Akdagh bei Amasya, Manissadjian 1165 (B), *MF401087, -; Gypsophila pacifica Komarov, JX274528,-; Gypsophila paniculata L., JN589150, FJ404908; Gypsophila patrinii 
Appendix 1. Continued.

Ser. 1, JN589076, -; Gypsophila patrinii 2, Russia, Altay Republic, Ongudayskiy Rayon, N side of Chuya valley near Belyy Bom 31 km SSE of Inya, Dry shrubland with Artemisia, S-exposed, limestone, $980 \mathrm{~m}, 50^{\circ} 21^{\prime} \mathrm{N}, 87^{\circ} 03^{\prime} \mathrm{E}, 15.7 .2002$, Raab-Straube 020105 (B), *MF401110, *MF401150; Gypsophila perfoliata L., Turkey, B4 Ankara, Yassihuyuk (ancient site of Gordion), ancient of Gordion proper, 39 $36^{\prime} \mathrm{N} 32^{\circ} 02^{\prime} \mathrm{E}$, alt. ca. $1100 \mathrm{~m}, 30.9 .1999$, Doring, Parolly \& Tolimir 7438 (B), *MF401114, *MF401139; Gypsophila petraea (Baumg.) Rchb., Romania, Reg. Ploiesti Bucegi, vale Jepilor zwischen Busteni cab. Caraman, Felsen, 1600-2000 m, 30.7.1965, Buttler \& Dietrich 8953 (B), *MF401095 (ITS1), *MF401151; Gypsophila pilosa Huds. 1, Spain, Murcia, Provincia de Albacete, Abzweigung von der Straße Hellin-Cieza in Richtung Agramón kurz vor Minateda, Felsen aus miozänen Kalken und Gipsflächen, ca. 520 m, 19.5.1983, Bayer \& Grau 34 (M), *MF401093, *MF401140; Gypsophila pilosa 2, Iran, Prov. Isfahan, at the entrance of Ghamsar to Ghohroud, ruderal vegetation of main Boullevard $5 \mathrm{~km}$ after Ghamsar, alt. $1667 \mathrm{~m}, 33^{\circ} 45^{\prime} 33.09^{\prime \prime} \mathrm{N}, 51^{\circ} 28^{\prime} 31.50^{\prime \prime} \mathrm{E}, 27.05 .2015$, Zarre \& Madhani 34287 (TUH) *MF401094, -; Gypsophila pilulifera Boiss. \& Heldr., JN589132, -; Gypsophila pinifolia Boiss. \& Hausskn. ex Boiss. 1, JN589050,-; Gypsophila pinifolia 2, Turkey, B6 Malataya, (Straße O, Malataya-36,5-Gürün, 140) ca. 4 km E Sarǐhací köyü an der Straße nach Malataya Felshang, 1480 m, 29.8.1971, Buttler 5774 (M), *MF401116, *MF401163; Gypsophila repens L. 1, KF737521, -; Gypsophila repens 2, Austria, Tirol, Stubaier Alpen, E-Hänge der Serlesscharte SW Maria Waldrast bei Matrei a. Brenner, 2100 m, 1.8.1983, Podlech 38401 (MSB), *MF401101, *MF401153; Gypsophila scorzonerifolia Ser., JN589100, -; Gypsophila silenoides Rupr., JN589049, -; Gypsophila stevenii Fisch. ex Schrank, JN589022, -; Gypsophila tomentosa L., Spain, Alicante, El Salobrar, 12.6.1986, Molero 30SWJ90 (33) (M), *MF401113, *MF401146; Gypsophila uralensis Less., KF317641, -; Gypsophila venusta Fenzl, Turkey, Anatolia, B6, Sivas, Zwischen Zara und Sivas, 15 km E Sivas, alt. 1250 m, Steppe auf Marmor, 22.7.1981, Nydegger 16995 (B), *MF401096, *MF401154; Gypsophila virgata Boiss., Iran, Prov. Azerbaijan orient., in saxosis faucium $38 \mathrm{~km}$ NNW Marand versus Jolfa, $1100 \mathrm{~m}$, Rechinger 43614 (B), *MF401107, -; Gypsophila viscosa Murray, Turkey, B5 Nevsehir, Goreme Tarihi Milli Parkim Goreme Valley, slopes SE of the Open Air Museum, ca. 1050-1100 m, tuff, secondary steppe and ruderal vegetation, 25.5.2006, Bircan \& Parolly 110 (B), *MF401084, *MF401137; Heterochroa desertorum (Bunge) Fenzl 1, JN589021, -; Heterochroa desertorum 2, Russia, Tuviskaja ACCP, Tuva, Distr., Ovjur, prope pagum Ak-Czyra Cleistogeneto-Nanphyteta Stepposa, 3.8.1973, Timokhina \& Daniljuk 6371 (M), *MF401118, *MF401171; Heterochroa violacea Fenzl, JN589068, -; Moehringia lateriflora (L.) Fenzl, JX274536, FJ404924; Petroana montana (Balf.f.) Madhani \& Zarre, Aden peninsula, Upper Crater, plateau SE of the Tower of Silence, ca. $120-170 \mathrm{~m}, 12^{\circ} 47^{\prime} \mathrm{N}, 45^{\circ} 02^{\prime} \mathrm{E}$, on fine-gravelly Pozzolane, 22.3.1997, Kilian, Hein \& Smalla NK 4487 (B), *MF401119, *MF401167; Petroana montserratii (Fern.Casas) Madhani \& Zarre 1, JN589155, -; Petroana montserratii 2, Spain, Albacete: pr. Ferez, 800 m, in rupi bus calcareis verticalibus, 19.8.1972, Casas s.n. (B), *MF401120, *MF401166; Petrorhagia prolifera (L.) P.W.Ball \& Heywood, GU440883, -; Petrorhagia saxifraga (L.) Link, JQ307895, FJ404930; Petrorhagia thessala (Boiss.) P.W. Ball \& Heywood, GU440885, -; Petrorhagia dubia (Raf.) G.López \& Romo, AY857974, -; Psammophiliella muralis (L.) Ikonn. 1, JN589037, -; Psammophiliella muralis 2, Germany, Bayern, MTB 6831/1: Acker nahe Mohrhof bei Poppenried/Höchstädt, 25.8.1987, E. Dörr s.n. (M), *MF401127, *MF401186; Psammosilene tunicoides W.C.Wu \& C.Y.Wu, JN589122, -; Saponaria glutinosa M.Bieb., HE602400, -; Saponaria griffithiana Boiss.,

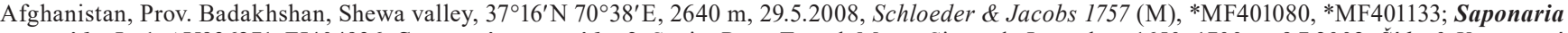
ocymoides L. 1, AY936271, FJ404936; Saponaria ocymoides 2, Spain, Prov. Teruel, Monte Sierra de Javambre, 1650-1700 m, 9.7.2002, Śída \& Vagnerová 3658 (M), *MF401077, *MF401130; Saponaria officinalis L. 1, AY594313, FJ404937; Saponaria officinalis 2, Japan, Kamite, Toyoshina-machi, Minamiazumi-gun, Nagano Pref., 550 m, 9.9.2002, dry bed river, Sugawara 2080906 (M), *MF401078, *MF401131; Saponaria prostrata Willd., Turkey, B6 Kahramanmaraş, 30 km to Göksun from Sariy, Bin Boğa Daği, above Yalak village, 2100-2400 m, 11.8.1997, Zarre 122 (MSB), *MF401079, *MF401132; Saponaria pumila Hayek, AY594311, -; Saponaria sicula Raf., -, Z83153; Silene alexandri Hillebr., EF060222, EF061382; Silene gallica L., U30959 (ITS1), U30985 (ITS), JX560214; Silene italica (L.) Pers., AY936258, KF305909; Silene repens Patrin, JX274527, DQ908842; Silene viscosa (L.) Pers., FN821148, FN821316; Silene vulgaris (Moench) Garcke, AY857967, EF674192; Stellaria media (L.) Vill., KF737498, FJ404953; Vaccaria hispanica (Mill.) Rauschert 1, X86896.1; Vaccaria hispanica 2, JF421553.1 (ITS2); Vaccaria hispanica 3, X83847.1 (ITS2); Velezia rigida L. 1, AY936269, -; Velezia rigida 2, GU440888, -. 